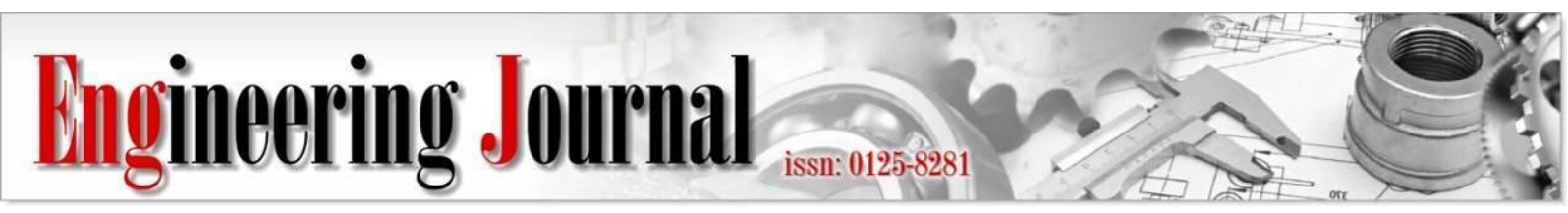

Article

\title{
Flood Risk Index for Land-Use Changes: Case Study of Pakpanang River Basin
}

\author{
Chonlatid Kittikhun ${ }^{\mathrm{a}}$, Sitang Pilailar ${ }^{\mathrm{b}, *}$, Suwatana Chittaladakorn ${ }^{\mathrm{c}}$, \\ and Eakawat Jhonpadit \\ Department of Water Resources Engineering, Faculty of Engineering, Kasetsart University, Bangkok, \\ Thailand \\ E-mail: aKchonlatid2019@gmail.com, bfengstpl@ku.ac.th (Corresponding author), cfengswc@ku.ac.th, \\ dEakawit36@gmail.com
}

\begin{abstract}
Flood Risk Index (FRI) is the multi-criteria linked with the factors of vulnerability; exposure, susceptibility, and resilience. In order to establish local FRI, crucial local information have to be accumulated. However, under the limitation of land-use data, particular techniques were applied in this study. CA Markov model was used to analyze the past missing land-use data and, also forecast the future land-use of Pakpanang river basin under conditions of plan and without plan. The ratio changes of forest, agriculture, wetland and water, and urban areas were considered. Then, the result of LULC spatial-temporal changes was then applied to Hec-HMS and Hec-Ras, with Arc GIS extension of Hec-GeoHMS and Hec-GeoRas software, in order to evaluate the flood hydrographs and flood severity in three municipalities corresponding to 100 -year return period rainfall. Afterward, the FRI of Pakpanang, Chianyai, and Hua-sai, which ranges from 0 to 1, were evaluated by using the modified FRI equations. It was found that sensitivity analysis in the area of forest on flood depth and inundation areas is incoherent. Nevertheless, without land-use planning, the changes in these three cities cause higher flood risk, where Chianyai is the riskiest as the $\mathrm{FRI}_{\mathrm{E}}$ is 0.58 . Further consideration of FRI and FRI proportion that reveals the FRI deviation indicates that to reduce flood risk, Chianyai would need the most resources and highest effort comparison to Pakpanang and Hua-sai.
\end{abstract}

Keywords: Flood, land-use planning, LULC, river basin management, flood vulnerability, flood risk index.

ENGINEERING JOURNAL Volume 24 Issue 5

Received 6 September 2019

Accepted 17 July 2020

Published 30 September 2020

Online at https://engj.org/

DOI:10.4186/ej.2020.24.5.25 


\section{Introduction}

Flood Risk Index (FRI) is a quantitative multi-criteria index which indicates the flood risk and vulnerability. It represents the degree of probability of flood occurrence and consequences damages as a scale from 0-1 (no damage to total damage) [1]. Thus, it is one of the parameters that can be used as a decision support tool, allowing quantitative rating the critical flood zones and considering the solutions or scenarios for the regions. Therefore, the impacts of future urban development can be evaluated, and the investment can also be primarily estimated further.

Although the FRI is advantageous in land-use planning, establishing the FRI is not so simple. The combination of different factors over various aspects of consideration leads to a more realistic FRI. It is influenced by several factors, including human settlements conditions, infrastructure, authority's policy and abilities, social imbalances, economic patterns [2]. For example, Goncalo, et al. [3] created an index under consideration of four main factors, i.e., hazard, exposure, vulnerability, and capacity. Cançado, et al. [4] studied flood risk assessment in an urban area and measured hazard and vulnerability provided by Risk = Hazard x Vulnerability. Okazawa et al. [5] created a global FRI based on both natural and social factors and the advanced flood risk index (AFRI) as a function of hazard and vulnerability metrics. Saudi et al. [6] created a flood risk index model based on a combination of several types of multivariate analysis, statistical process control (SPC) and ANN method. Karmaoui [7] created an index model assessing the risk at triple components, i.e., the flood occurrence probability, vulnerability, and consequences.

Understandably, providing the flood risk assessment is rather site-sensitive. Thus, this study presents a particular technique for flood risk analysis of Pakpanang River where encounters severe flood several times during the last decade. The uses of geographical information system (GIS) combining with the hydrodynamics mathematical model are applied with the considerations of various factors such as population, infrastructure, flood protection measures, and warning system. Hence, this local FRI can be used to quantitatively compare the flood risk under the existing land-use and the planned condition eventually.

\section{Floods in Pakpanang River Basin}

Pakpanang River Basin is located on the east coast of the Southern peninsular of Thailand. The basin is 3,500.52 Sq.Km. in which three municipalities of Pakpanang, Chianyai, and Hua-sai, have always been affected by the flood in monsoon season from August to January. Based on the historical reports of The Land and Development Department (LDD) as summarized in Table 1, the damages due to seasonal flood has significantly increased over these latest ten years, as a result of both natural factors and human influences. The inundation area in January 2014 is almost 1.5 times of the inundation area in December 2002.
It has been found that the agricultural area, urban area, and wetland also increased, whereas the forest area decreased. Figure 1 presents the changes in land-use in three municipalities under our consideration, in 2002, 2007, 2012, and 2014. It clearly shows the yearly increase of agricultural area, which is about $12 \%$, whereas the yearly decrease of urban, forest and wetland are 15\%,18\% and $10 \%$, respectively. It might be too hasty to conclude that the additional flood damage is due to land-use changes, but it is one of the factors that should be considered relevant in the matter in this study.

\section{Pakpanang Land-Use Change Study}

It is noticeable that land-use change should be understood based on dynamic information. The spatial distribution of the specific land cover and land-use classes has been modeled, for over a decade, by several methods. Omar et al. [8] and Mondal et al. [9] mentioned that two representative models are the Markov chain model and the CA (Cellular Automata) Markov model. However, later, the CA Markov model combines both the concept of a CA filter and Markov chain procedure. It achieved a significant improvement in incorporating the spatial contingency information when making predictions of land-use, and land cover (LULC) changes. Pontius and Malansons [10] reported their success in applying CA Markov model when predicting land cover changes in Central Massachusetts, Jafar et al. [11] applying CA Markov mode for predicting land-Use in Gilan province in the northwest of Iran, and Hua [12] applied the model on LULC changes in Malacca River watershed in Malaysia. The result provided valuable information for land planning.

Studying the effects of past and current land-use on the flood risk of three municipalities in Pakpanang River Basin, the LULC spatial-temporal changes in the watershed are classified as water, forest area, agricultural area, urban area, and wetland. Figure 1 presents the available land-use data with the inundated area of the years 2002, 2007, 2012, and 2014. Then, the hind cast land-use of the missing years and the forecast land-use of the future were analyzed by using CA Markov model by IDRIS Version 17. Besides, this study also similarly analyzed the future trend based on applying the land-use planning data of the years 2010, 2014 and 2018 collected from Department of Public Works and Town and Country Planning (DPT), as shown in Fig. 2, as well.

Under the probability of changing value and a transition of changing ratio value of past land-use, the results of hind cast and forecast land-use are shown in Fig. 3 with the comparisons of each category of land- used type presented in Table 2.

Comparing the forecast land-use change under the actual circumstance with the forecast planned, the trends are different in all land-use types. Under the actual trend of land-use change, the water/wetland will be decreased and replaced by the urban and forest area whereas under the planned land-use, the urban and forest will be replaced 
by the agricultural area. It is worth noting that different land-use change trends may cause different levels of flood risk. Therefore, it will be evaluated in term of FRI.

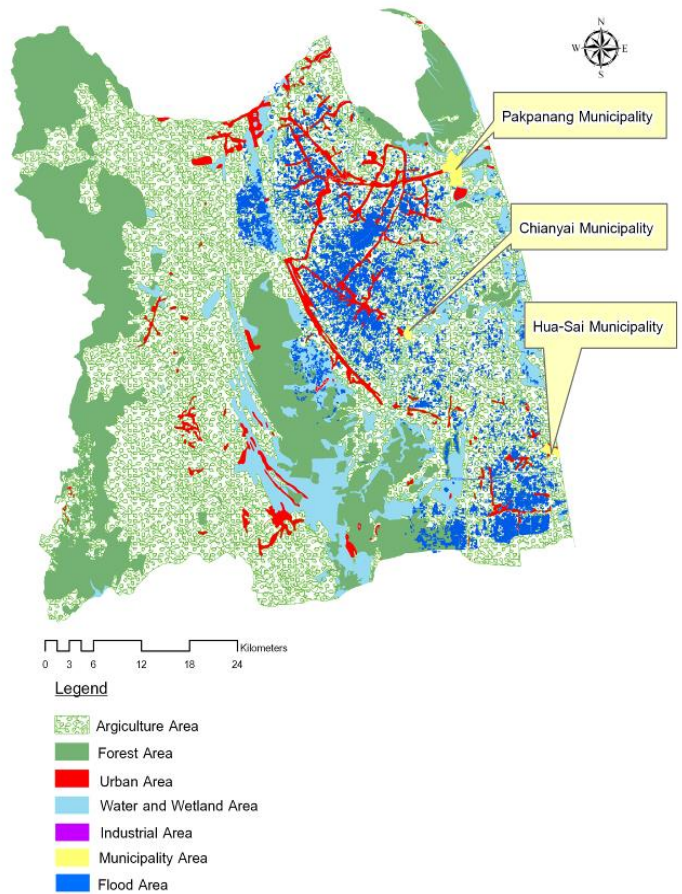

(A) Land-use and Flood Area in 2002

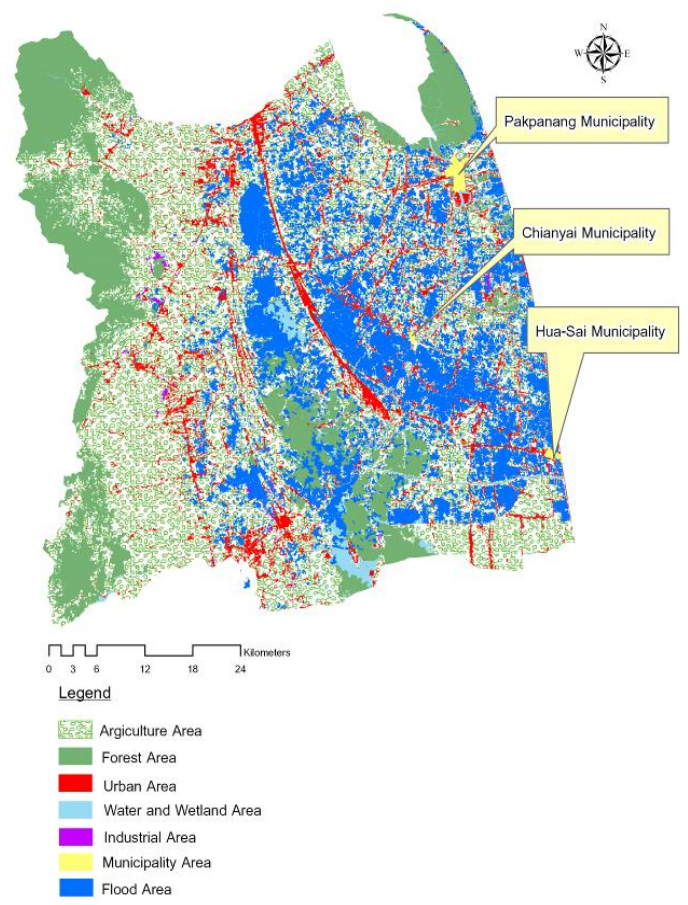

(C) Land-use and Flood Area in 2012

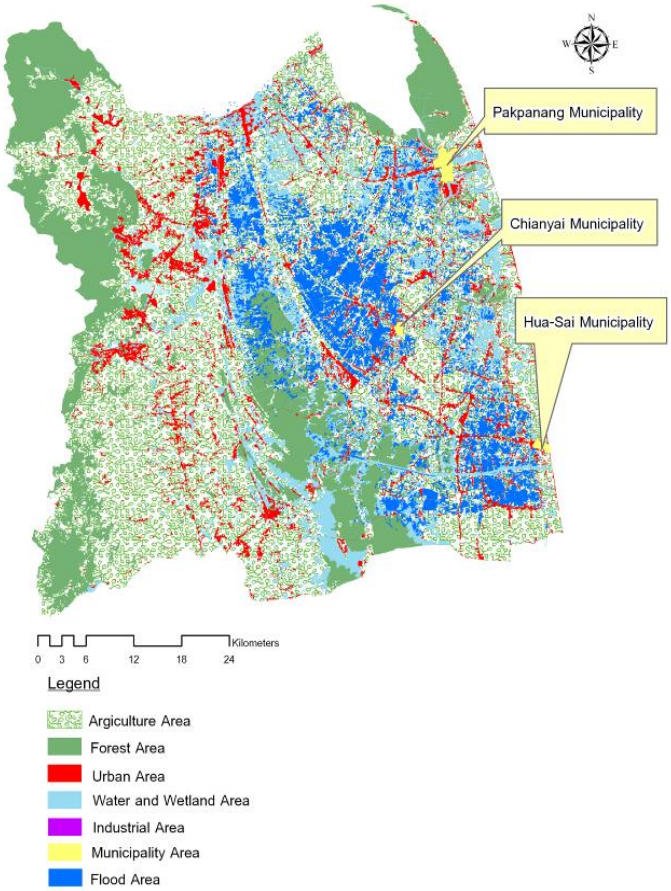

(B) Land-use and Flood Area in 2007

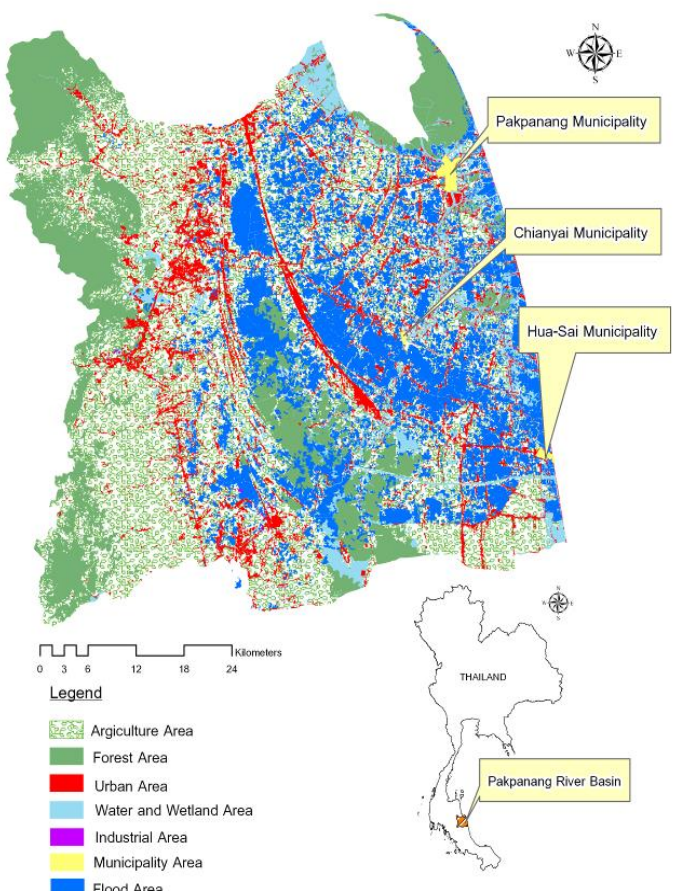

(D) Land-use and Flood Area in 2014

Fig. 1. Comparisons of land-use, and inundated area, in Pakpanang, Chianyai, and Hua-sai, in 2002, 2007, 2012 and 2014. 
Table 1. Damages on each land-use type due to seasonal flood, in 2002, 2007, 2012 and 2014.

\begin{tabular}{|c|c|c|c|c|c|c|c|}
\hline Year & $\begin{array}{c}\text { Urban } \\
\text { (Sq.Km.) }\end{array}$ & $\begin{array}{l}\text { Agriculture } \\
\text { (Sq.Km.) }\end{array}$ & $\begin{array}{l}\text { Forest } \\
\text { (Sq.Km.) }\end{array}$ & $\begin{array}{l}\text { Water\&Wetland } \\
\text { (Sq.Km.) }\end{array}$ & $\begin{array}{l}\text { Industrial } \\
\text { (Sq.Km.) }\end{array}$ & $\begin{array}{l}\text { Total flood area } \\
\text { (Sq.Km.) }\end{array}$ & $\begin{array}{c}\text { Flood duration } \\
\text { (day) }\end{array}$ \\
\hline 2002 & 190.00 & $2,600.10$ & 292.00 & 401.54 & 16.87 & 387.90 & $5-15$ \\
\hline 2007 & 199.40 & $2,742.03$ & 296.88 & 246.09 & 16.10 & 421.80 & $5-20$ \\
\hline 2012 & 218.63 & $2,809.01$ & 324.80 & 132.82 & 15.26 & 541.70 & $5-10$ \\
\hline 2014 & 220.99 & $2,818.32$ & 337.77 & 108.31 & 15.12 & 549.70 & $5-10$ \\
\hline
\end{tabular}

Source: The Land and Development Department, 2015.

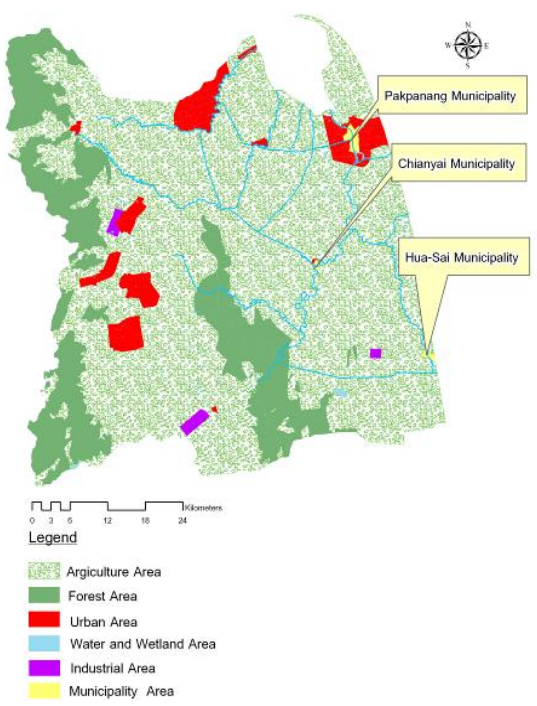

(A) Land-use Planning in 2010

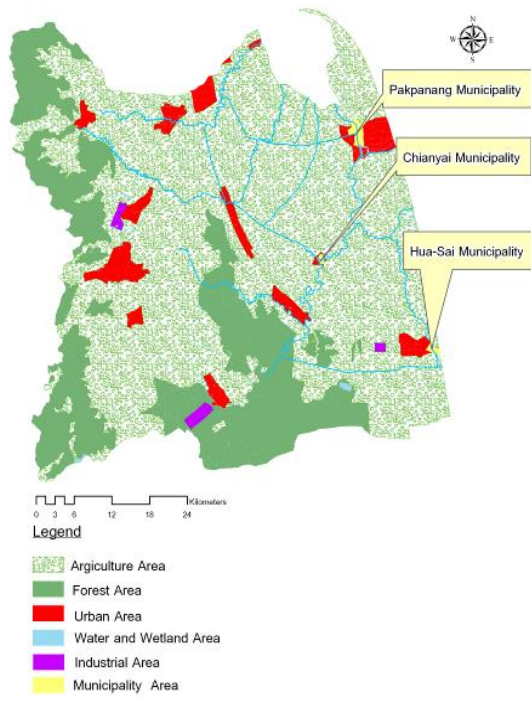

(B) Land-use Planning in 2014

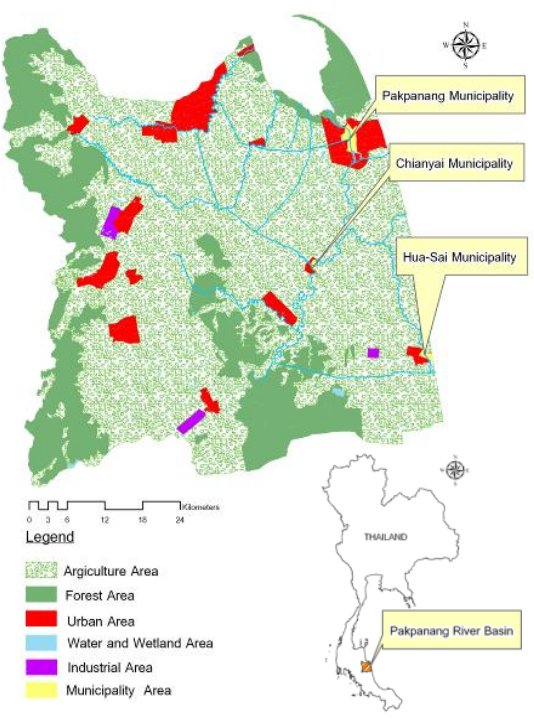

(C) Land-use Planning in 2018

Fig. 2. Planned land-use, of 2010, 2014, 2018.

Source: Department of Public Works and Town Planning, 2018.

Table 2. Comparisons of each category of land-use type, the result of land-use ratio hind cast and forecast by CA Markov.

\begin{tabular}{|c|c|c|c|c|c|c|c|c|c|c|c|c|c|c|c|c|c|c|c|c|}
\hline Existing Condition & & & & & & & & & & & Year & & & & & & & & & \\
\hline Land use type & 2002 & 2007 & 2008 & 2009 & 2010 & 2011 & 2012 & 2013 & 2014 & 2015 & 2016 & 2017 & 2018 & 2019 & 2020 & 2021 & 2022 & 2023 & 2024 & 2025 \\
\hline Urban & 190.00 & 199.40 & 204.73 & 207.88 & 210.79 & 213.64 & 218.63 & 218.63 & 220.99 & 222.86 & 224.57 & 226.27 & 228.00 & 229.40 & 230.50 & 231.70 & 232.95 & 233.92 & 234.67 & 235.53 \\
\hline griculture & $2,600.10$ & $2,742.03$ & $2,756.85$ & $2,770.30$ & $2,789.14$ & $2,796.42$ & 2,809.01 & $2,809.01$ & $2,818.32$ & 2,821.12 & 2,823.33 & $2,825.09$ & $2,828.87$ & $2,828.72$ & $2,828.55$ & $2,828.22$ & 2,828.91 & 2,827.40 & $2,825.89$ & $2,824.27$ \\
\hline & 292.00 & 296.88 & 301.93 & 306.73 & 312.31 & 316.62 & 324.80 & 330.90 & 337.77 & 342.95 & 348.19 & 353.23 & 358.18 & 362.94 & 367.77 & 372.21 & 376.74 & 381.07 & 385.38 & 389.46 \\
\hline ter/Wetland & 401.54 & 5.09 & & 199.81 & 172.65 & 158.31 & 132.82 & 126.72 & 108.31 & 98.59 & 89.56 & 81.19 & 70.84 & 64.94 & 59.30 & 54.08 & 47.76 & 44.07 & 40.64 & 37.40 \\
\hline ndustrial & 16.87 & 16.10 & 15.94 & 15.80 & 15.64 & 15.52 & 15.26 & 15.26 & 15.12 & 14.99 & 14.87 & 14.74 & 14.63 & 14.52 & 14.40 & 14.29 & 14.17 & 14.07 & 13.95 & 13.86 \\
\hline
\end{tabular}

\begin{tabular}{|c|c|c|c|c|c|c|c|c|c|c|c|c|c|c|c|c|c|c|c|c|}
\hline Planning Condition & & & & & & & & & & & Year & & & & & & & & & \\
\hline Land use type/year & 2002 & 2007 & 2008 & 2009 & 2010 & 2011 & 2012 & 2013 & 2014 & 2015 & 2016 & 2017 & 2018 & 2019 & 2020 & 2021 & 2022 & 2023 & 2024 & 2025 \\
\hline & 244.66 & 162.04 & 152.15 & 144.30 & 137.07 & 131.42 & 125.97 & 121.74 & 117.93 & 115.03 & 112.38 & 110.36 & 108.42 & 106.96 & 105.52 & 104.59 & 103.72 & 103.44 & 102.85 & 102.40 \\
\hline Igriculture & 2504.10 & 2697.04 & 2718.66 & 2735.17 & 2754.59 & 2769.35 & 2786.05 & 2800.04 & 2813.10 & 2825.30 & 2836.95 & 2847.30 & 2856.99 & 2866.64 & 2875.46 & 2883.39 & 2891.22 & 2898.17 & 2905.08 & 2911.51 \\
\hline & 639.82 & 561.42 & 548.09 & 536.27 & 524.34 & 513.29 & 501.52 & 490.93 & 480.90 & 470.85 & 460.77 & 451.69 & 443.34 & 433.85 & 425.71 & 417.94 & 410.19 & 402.86 & 395.74 & 389.07 \\
\hline Wetlar & 100.18 & 66.55 & 65.19 & 64.36 & & 63.37 & 62.58 & 62.18 & 61.95 & 61.63 & 61.36 & 61.16 & 60.85 & 60.61 & 60.45 & 60.26 & 60.12 & 59.93 & 59.80 & 59.66 \\
\hline ndustrial & 11.76 & 13.48 & 16.43 & 20.42 & 20.77 & 23.09 & 24.41 & 25.63 & 26.64 & 27.71 & 29.06 & 30.00 & 30.92 & 32.46 & 33.37 & 34.33 & 35.27 & 36.13 & 37.06 & 37.88 \\
\hline
\end{tabular}

Remarks: : Dataset used for the forecast. 

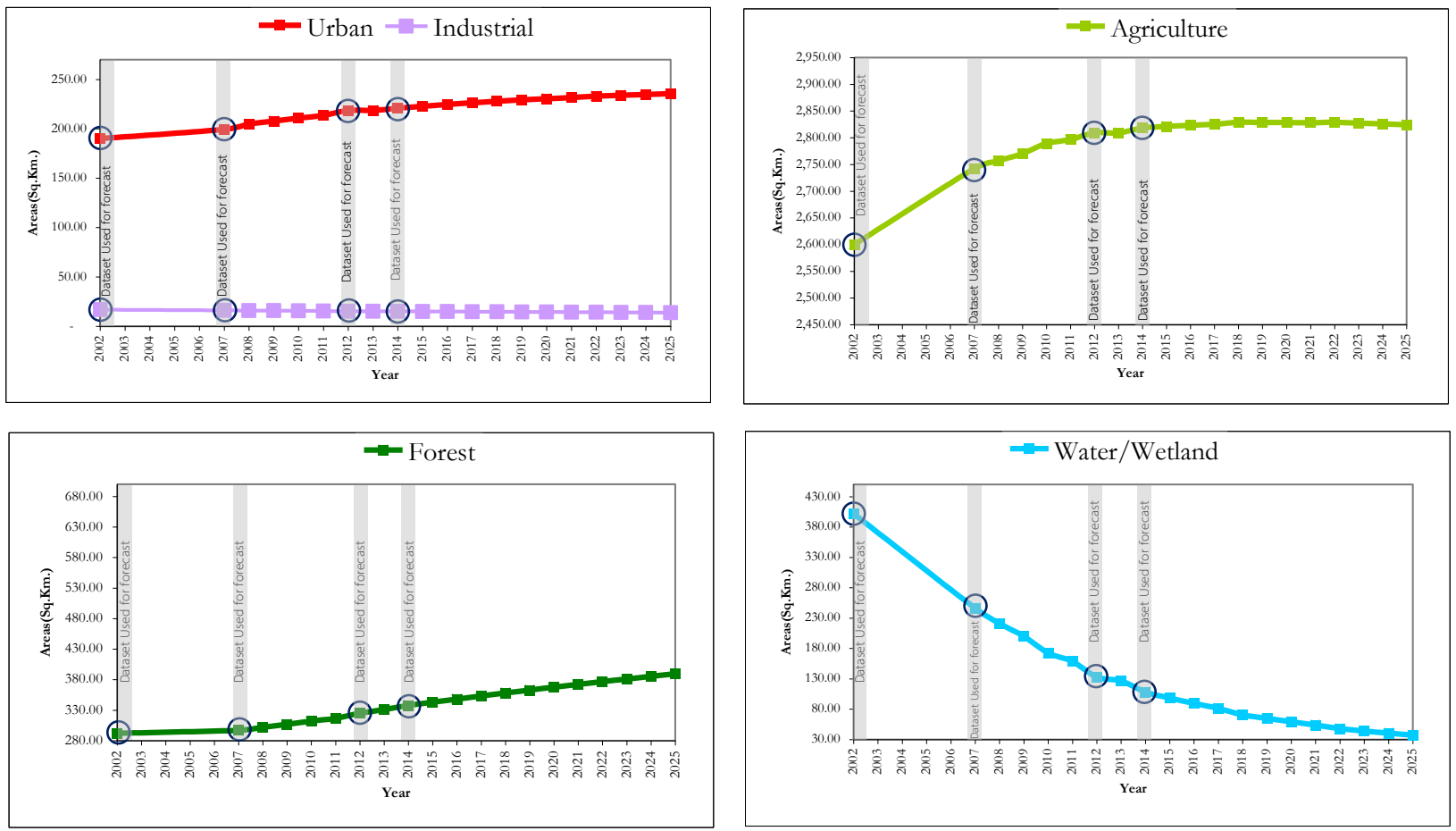

(A) Results of hind cast and forecast LULC based on the actual land-use change in 2007-2025
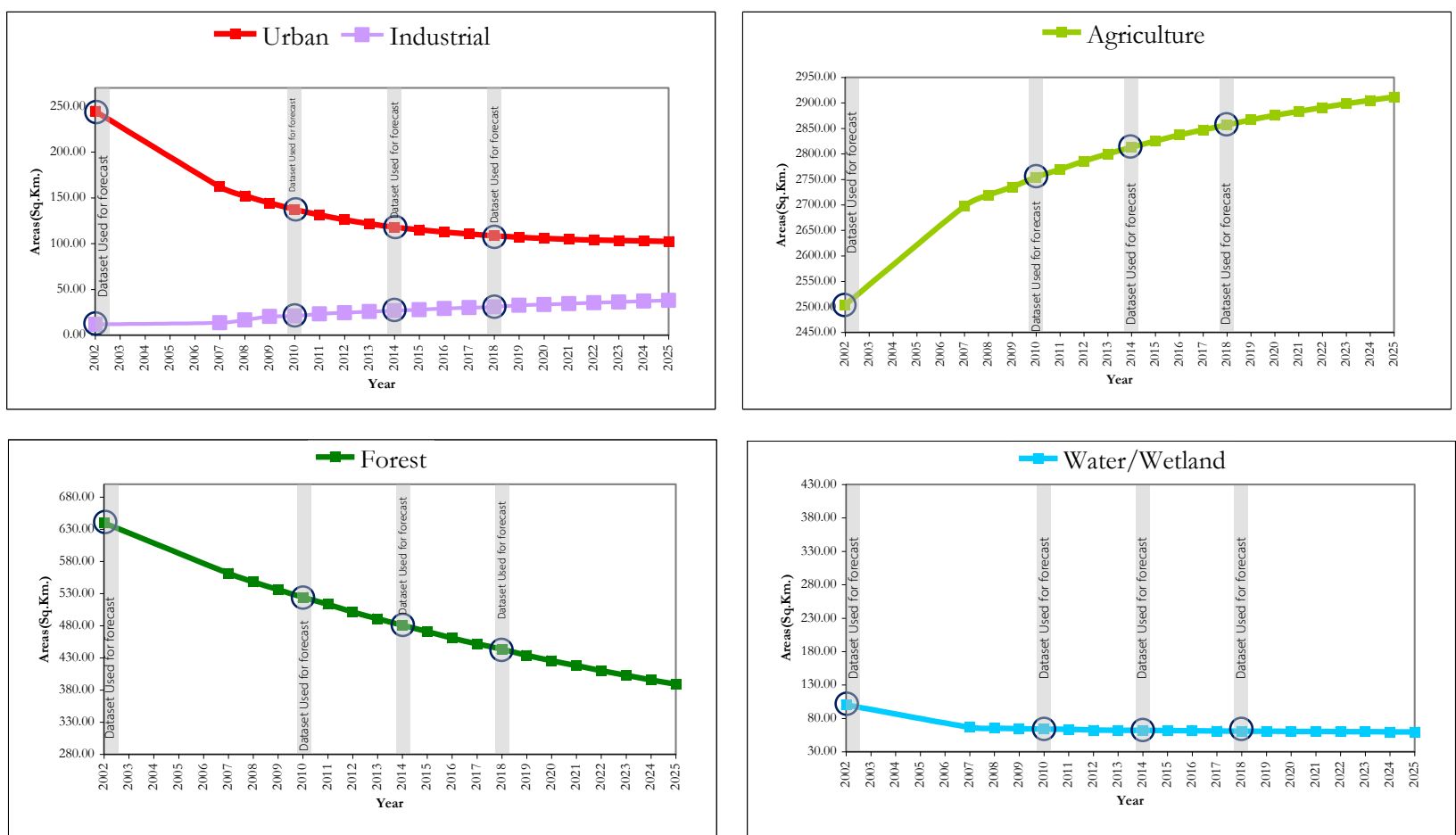

(B) Results of hind cast and forecast LULC based on the planed land-use change in 2007-2025

Fig. 3. Results of hind cast and forecast LULC in $2007-2025$, by specifying the years that data is available. 


\section{Pakpanang Flood Evaluation}

Based on the LULC spatial-temporal changes in Pakpanang River Basin that were previously analyzed, the flood behaviors in 3 municipalities of Pakpanang, Chianyai and Hua-sai corresponding to 100 year-return period rainfall were then evaluated by applying the concept of grid base for rainfall-runoff and $\mathrm{CN}$ Curve Number, as shown in Fig. 4., which is modified from [13].

According to the processes presented in Fig. 5, the stream network in 16 sub-basins was firstly generated from digital elevation model (DEM) by using the Arc GIS extension of Hec-GeoHMS software [14] and [15], as shown in Fig. 6. Then, the flood hydrographs were analyzed with the composite curve number $(\mathrm{CN})$ which is shown in Table 3. Further, the flood map under various conditions of flows was executed by using Hec-GeoRAS model.

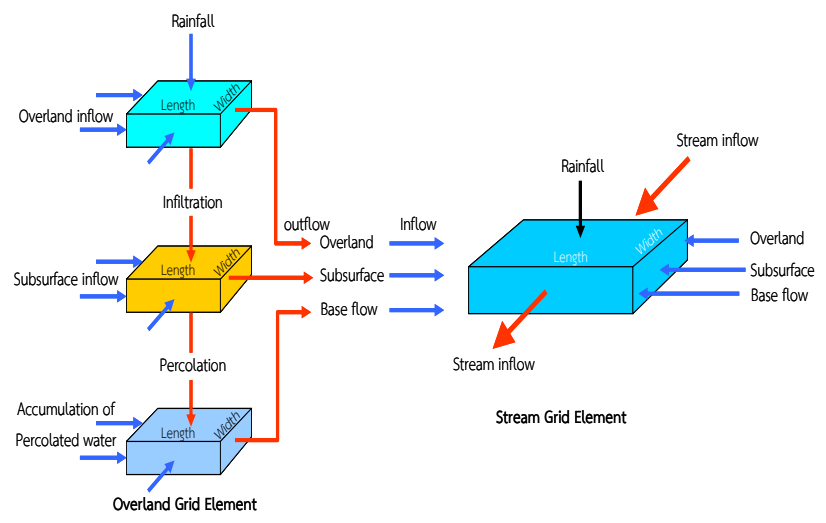

(Applied from Jung et al. [13].)

Fig. 4. Grid base for rainfall-runoff and CN Curve Number Process [13].

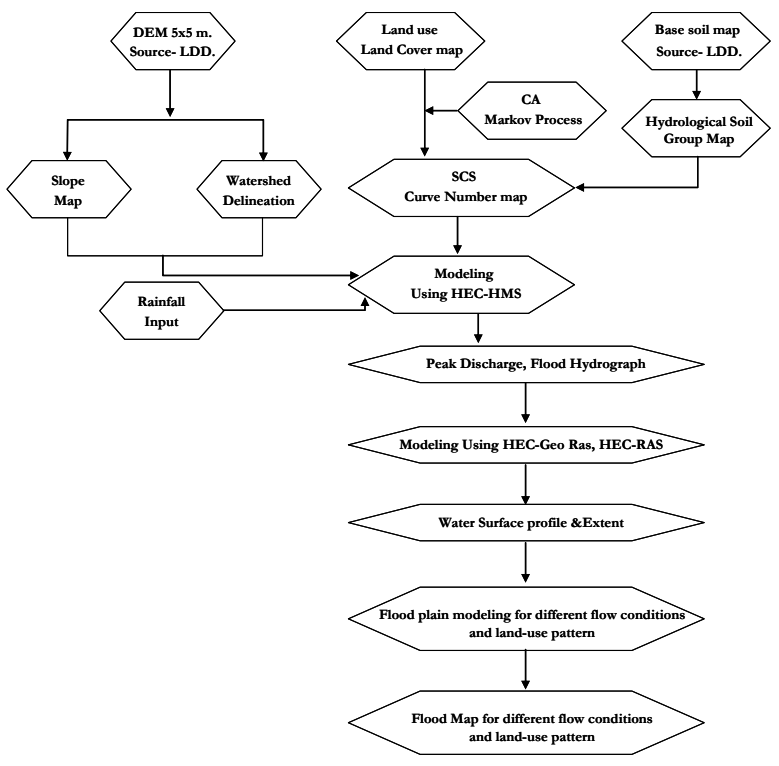

Fig. 5. Pakpanang flood evaluation processes.

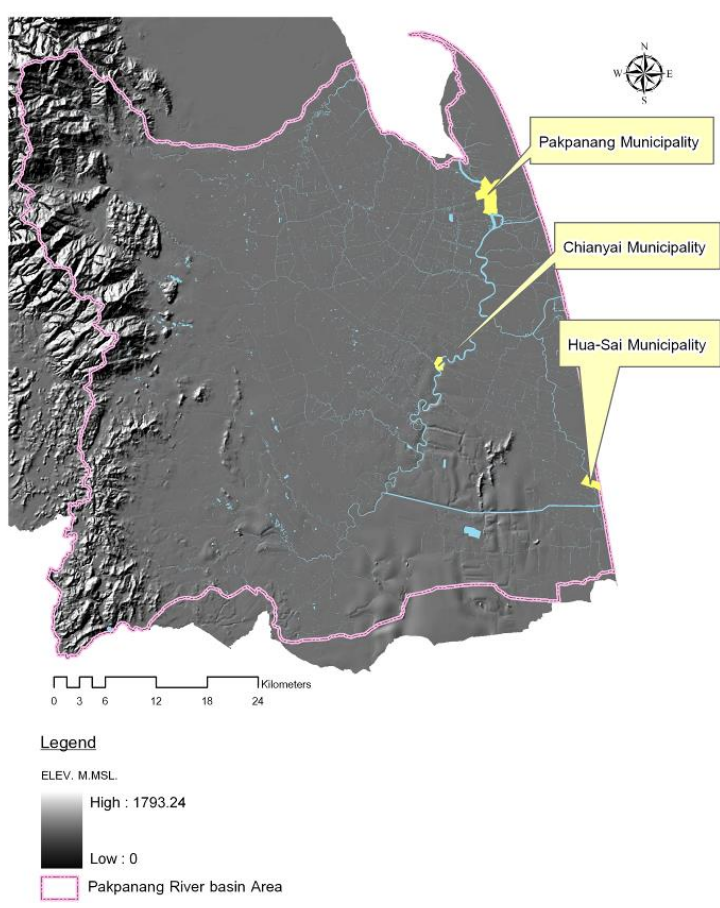

(A) DEM of the Pakpanang River Basin

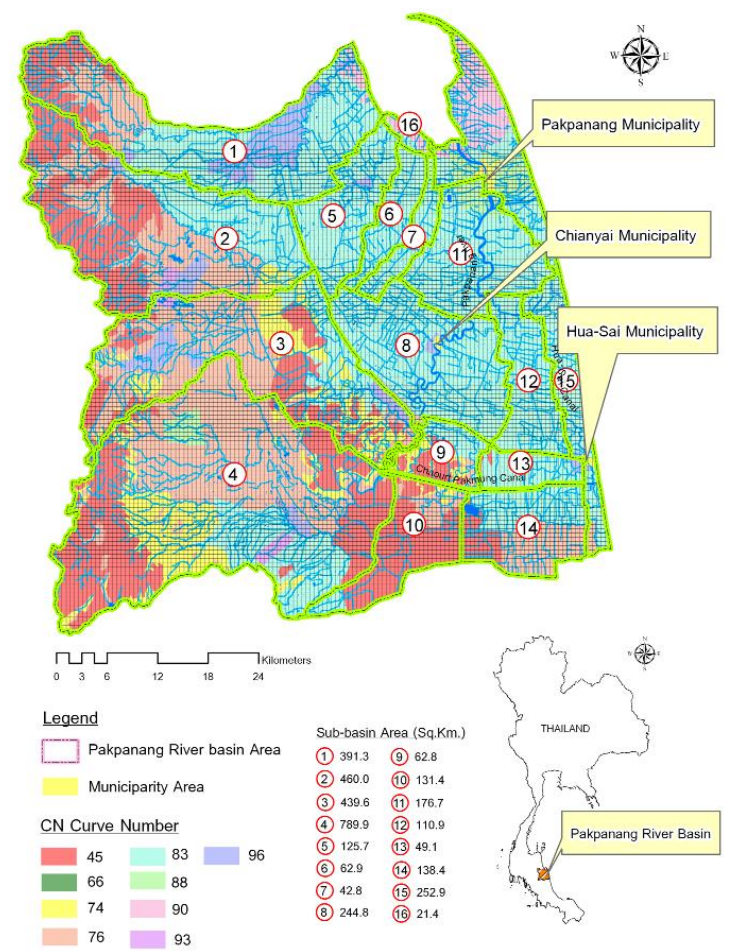

(B) Sub-Basin of the Pakpanang River Basin and Grid Cell size CN Curve Number

Fig. 6. Generated Pakpanang stream network. 
Table 3. Study area runoff curve number.

\begin{tabular}{lcccc}
\hline \multirow{2}{*}{$\begin{array}{c}\text { Land-use } \\
\text { Type }\end{array}$} & \multicolumn{4}{c}{ Hydrological Soil Class } \\
\cline { 2 - 5 } & $\mathrm{A}$ & $\mathrm{B}$ & $\mathrm{C}$ & $\mathrm{D}$ \\
\hline Urban & 83 & 90 & 93 & 96 \\
Agriculture & 74 & 83 & 88 & 90 \\
Forest & 45 & 66 & 77 & 83 \\
Water & 100 & 100 & 100 & 100 \\
Wetland & 100 & 100 & 100 & 100 \\
Industrial & 81 & 88 & 91 & 93 \\
\hline
\end{tabular}

Remark:

- Soil Class A is Runoff Potential low, Vertical Hydraulic Conductivity K Value Greater than 20 inch/day

Soil Class B is Runoff Potential Moderate, Vertical Hydraulic Conductivity K Value Between 10 and 19 inch/day

- Soil Class C is Runoff Potential Moderate high, Vertical Hydraulic Conductivity K Value Between 3 and 10 inch /day

- Soil Class D is Runoff Potential high, Vertical Hydraulic Conductivity K Value Between 3 inch/day

\subsection{Model Calibration and Validation}

In order to simulate the flood events of the concerned periods, the mathematic models, Hec-GeoHMS and HecGeoRAS have to be firstly calibrated and validated.

The flood event in 2012 has been selected as the rainfall data during Oct,15 2012 to Jan,20 2013 was input under the upstream boundary at Cha-Uat district of Pakpaanng river, with side flows of Chianyai canal, Huatud canal, and downstream boundary at gulf of Thailand, as depicted in Fig. 7. The simulated water level and flow and at 3 stations, as shown in Fig. 8, was compared with observed data. Comparisons in Fig. 9(A1) and Fig. 9(B) presents good agreement of both HecGeoHMS and Hec-GeoRAS between the simulated and observed data model calibrations. Afterword, the model validation process has been proceeded under the flood event in 2014. The simulated water level and flow at 3 stations show good agreement with recorded data, as presented in Fig. 9(A2) and Fig. 9(C)

\subsection{Comparison of Flood Hydrograph due to Land- Use Changes}

Since it has been assumed that the land-use and land cover is one of the crucial factors of flood risk, the flood effects were analyzed based on four conditions of LULC; which are (1) actual land-use in 2007 (2) DPT planned land-use of 2007 (3) forecast land-use of 2025, based on actual condition, and (4) forecast planned land-use of 2025 , based on DPT plan.

The simulated flood hydrographs and inundation area in 2007 and 2025 due to the 100-year return period rainfall, $150 \mathrm{~mm}$. / day for 1-3 days, are shown in Fig. 10, Fig. 11 and Fig. 12, respectively. The peak flood and flood durations are also summarized in Table 4. The results indicate that the land-use change under the actual conditions, both in 2007 and 2025, cause a higher severity in all consideration aspects comparing with the flood under the planned land-use condition.

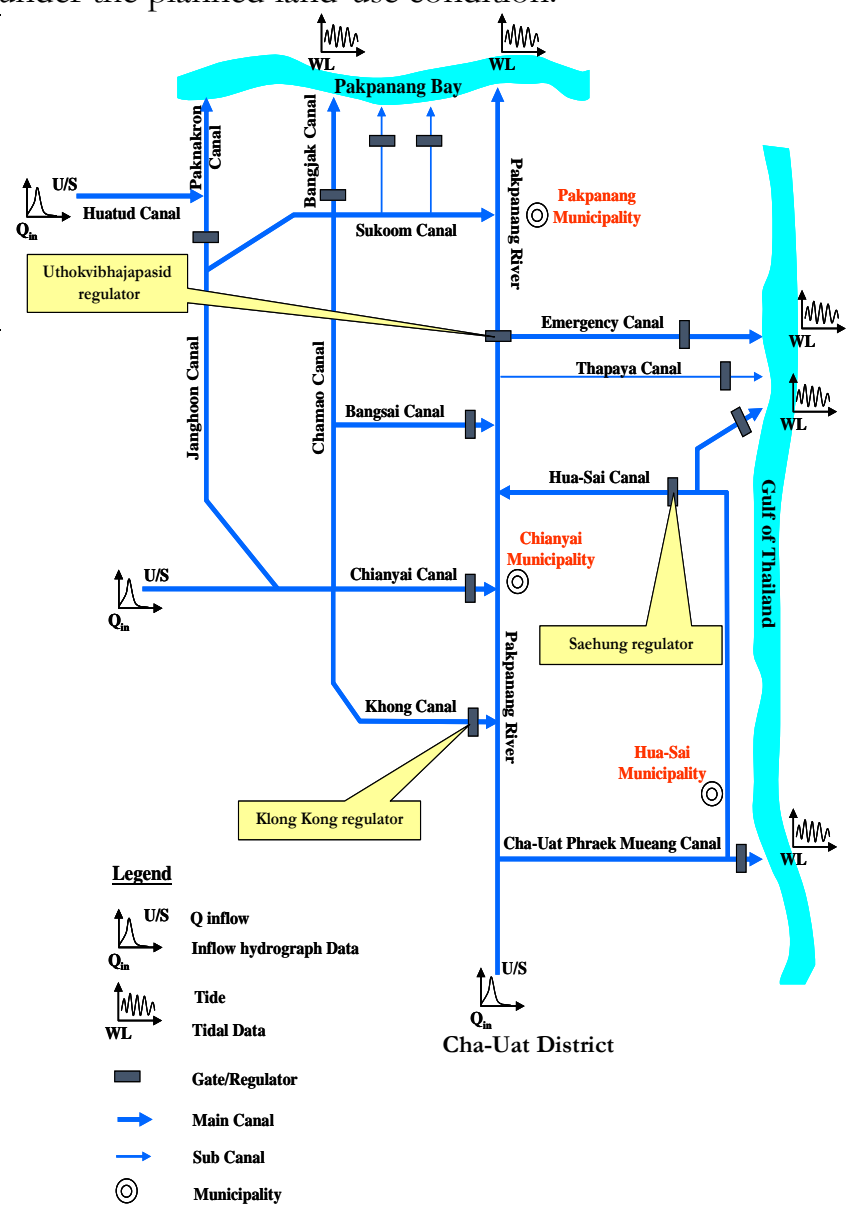

Fig. 7. Schematic flow of Pakpanang river basin.

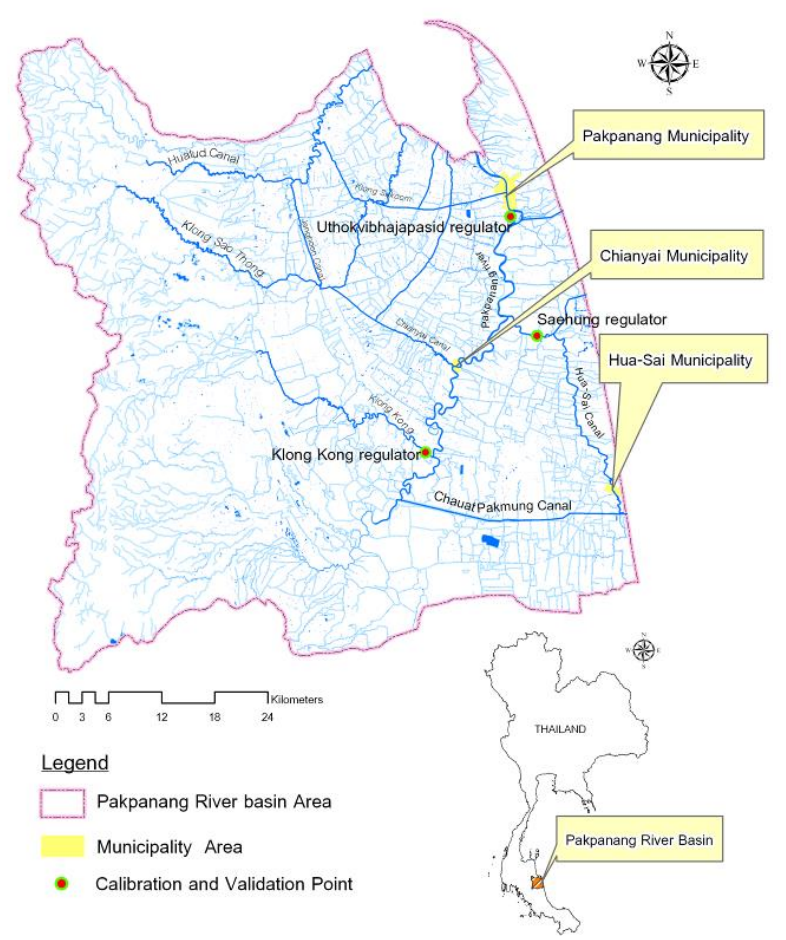

Fig. 8. Selected three stations for the modelcalibration and validation. 


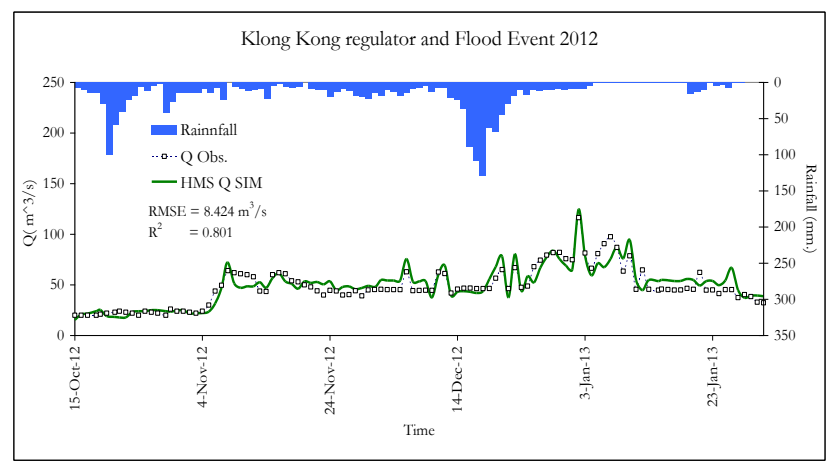

(A1) Show Hec-GeoHMS calibration result
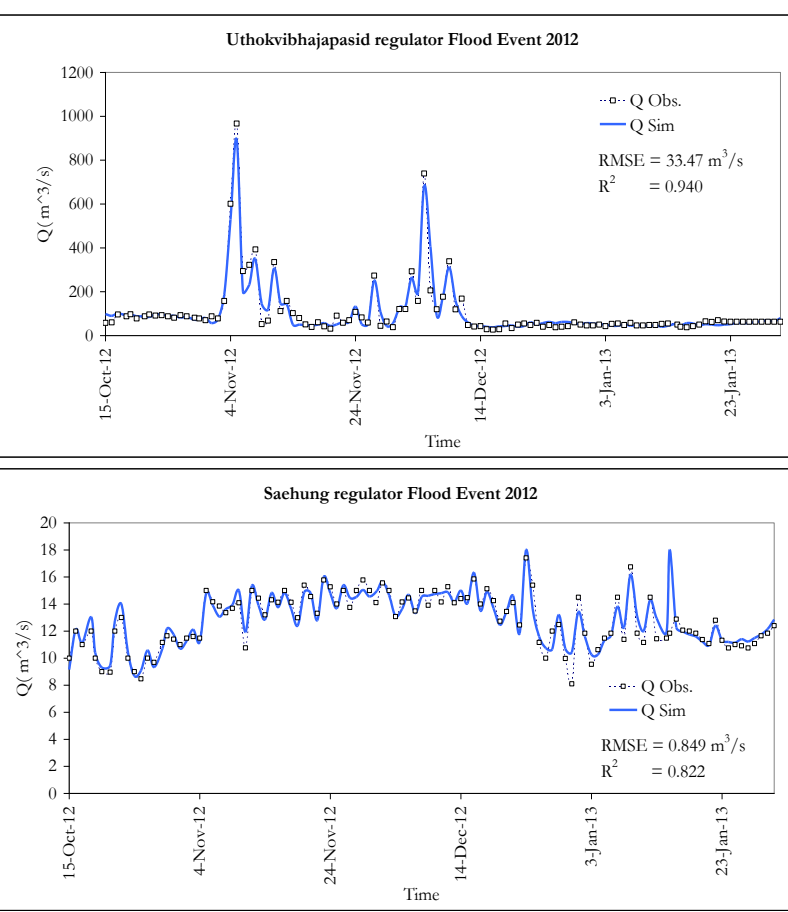

Klong Kong regulator and Flood Event 2014

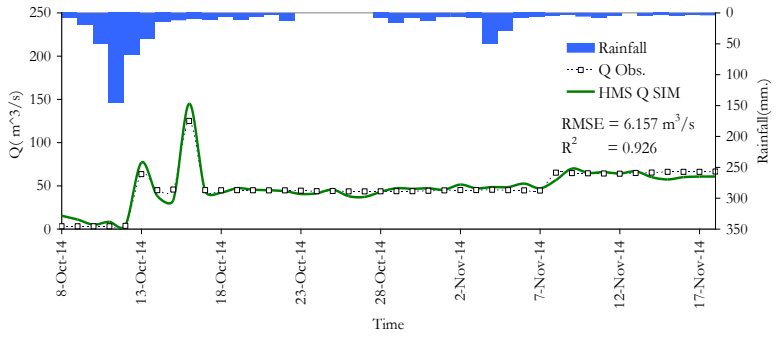

(A2) Show Hec-GeoHMS validation
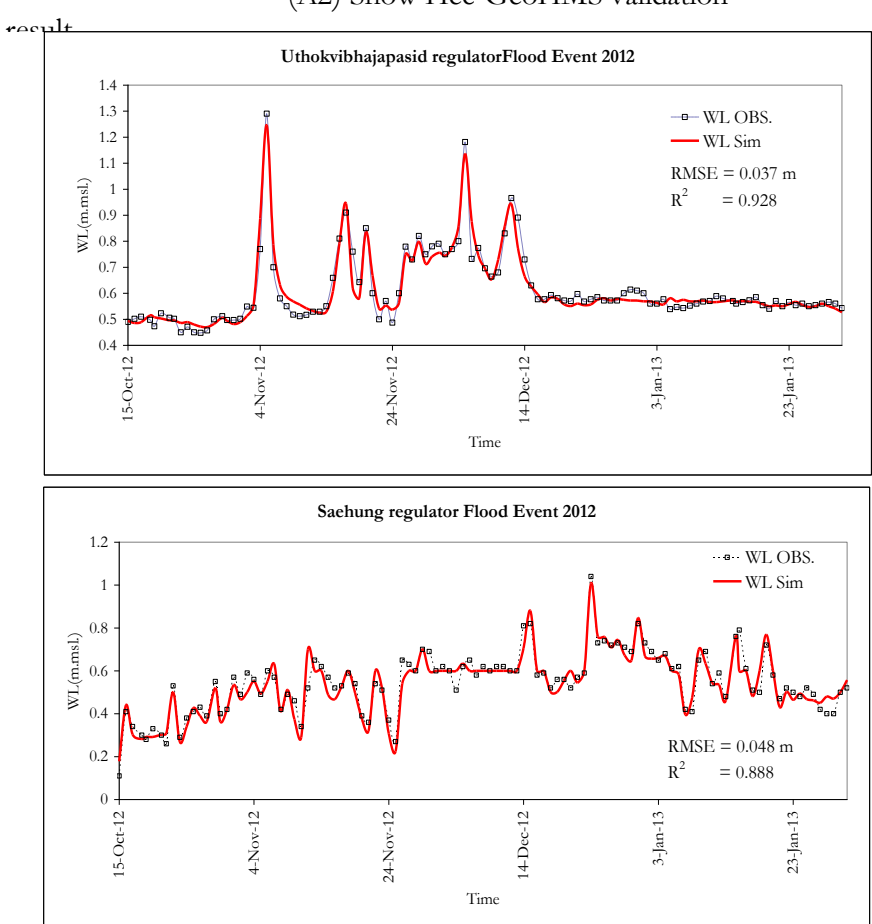

(B) Show Hec-GeoRAS calibration result Flood Event 2012
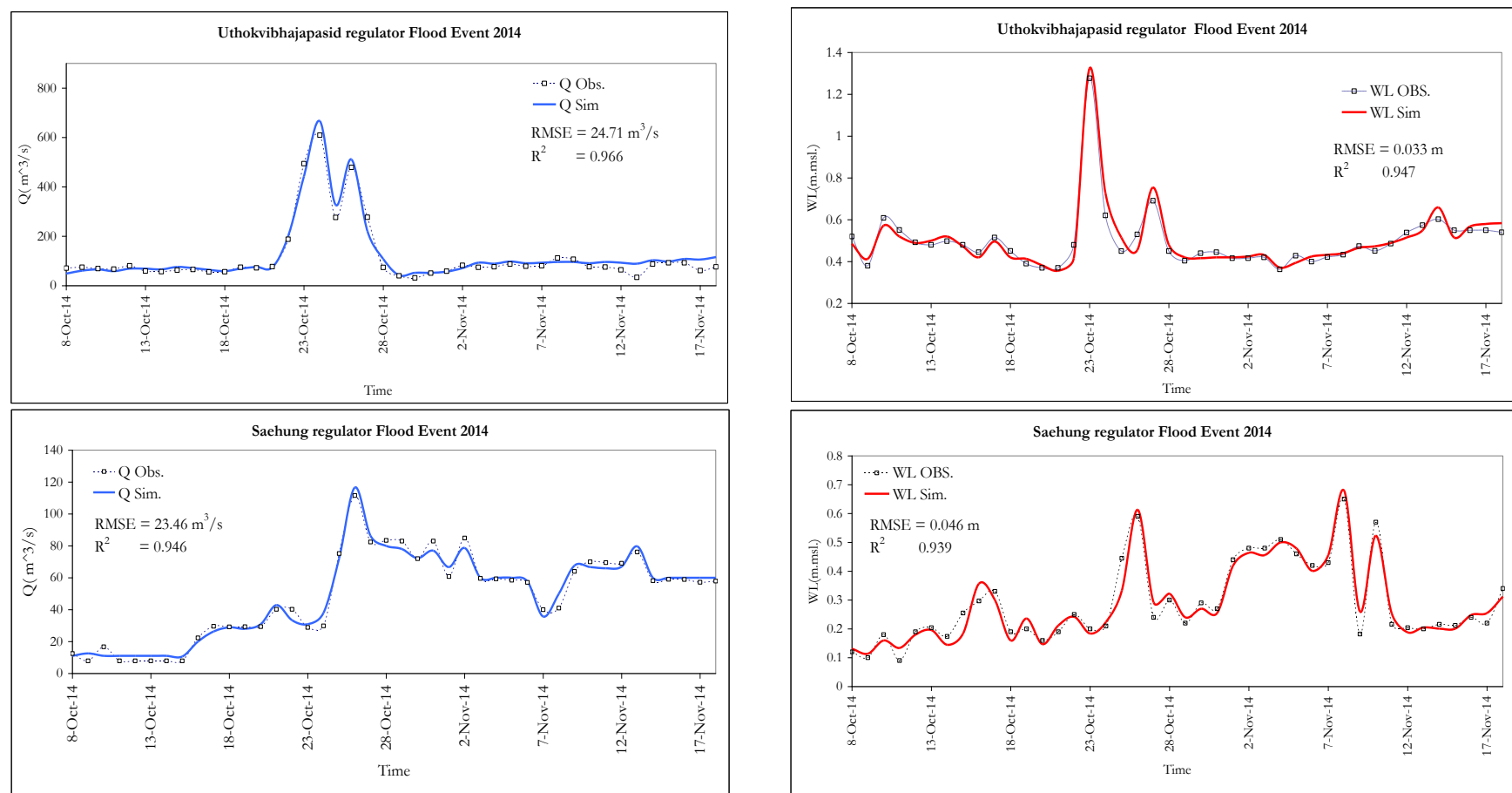

(C) Show HEC-GeoRAS validation result Flood Event 2014

Fig. 9. Hec-GeoHMS and Hec-GeoRas Calibration and Validation result. 

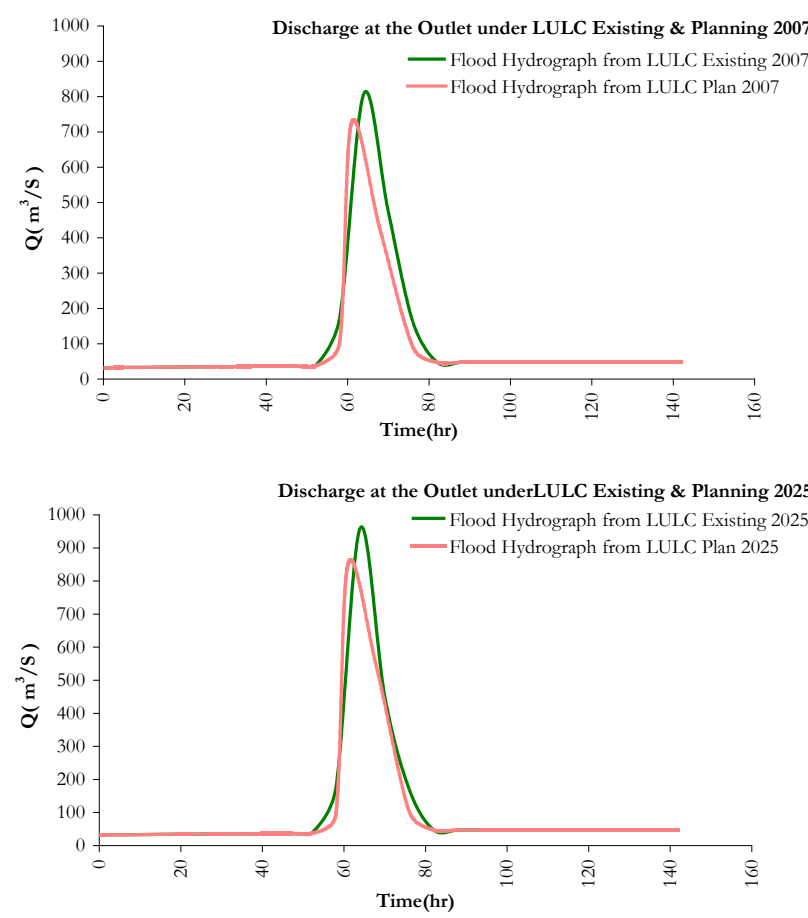

Fig. 10. Simulated flood hydrographs under 100-year return period rainfall, at the outlet, under existing land-use and planed land-use in 2007, 2025.

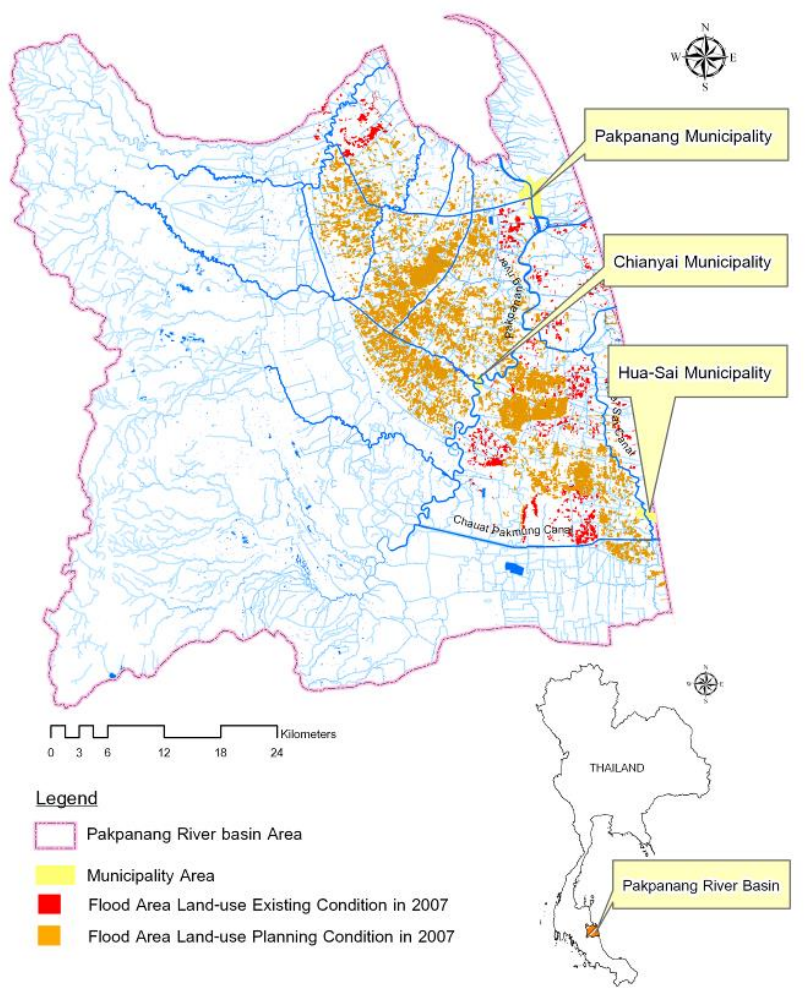

Fig. 11. Simulated flood under 100-year return period rainfall, under existing land-use and planed land-use in 2007.

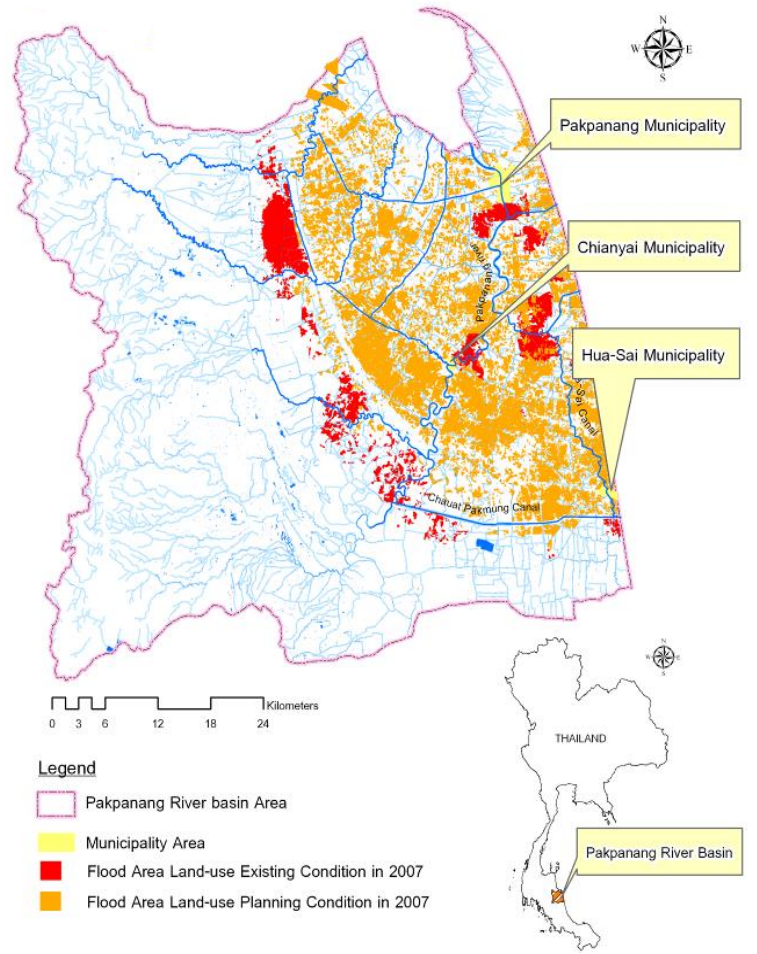

Fig. 12. Simulated flood under 100-year return period rainfall, under existing land-use and planed land-use in 2025.

Table 4. Comparisons of flood effect, under 100-year return period rainfall, under LULC in 2007 and 2025.

\begin{tabular}{lcccc}
\hline & $\begin{array}{c}\text { LULC } \\
\text { Existing }\end{array}$ & $\begin{array}{c}\text { LULC } \\
\text { Planning }\end{array}$ & $\begin{array}{c}\text { LULC } \\
\text { Existing }\end{array}$ & $\begin{array}{c}\text { LULC } \\
\text { Planning }\end{array}$ \\
& 2007 & 2007 & 2025 & 2025 \\
\hline $\begin{array}{l}\text { Flood } \\
\text { Dischrage } \\
\text { (Cu.m./Sec) }\end{array}$ & 808.00 & 726.00 & 960.00 & 850.00 \\
$\begin{array}{l}\text { Flood } \\
\text { Duration(hr.) }\end{array}$ & 20.00 & 15.00 & 20.00 & 15.00 \\
$\begin{array}{l}\text { Flood Area } \\
\text { (Sq.Km.) }\end{array}$ & 421.00 & 355.00 & 464.00 & 392.00 \\
$\begin{array}{l}\text { Time Peak } \\
\text { interval to }\end{array}$ & & & & \\
Outlet(day) & 8.00 & 10.00 & 5.50 & 6.50 \\
\hline
\end{tabular}

\section{FRI Formulation}

\subsection{FRI Concept}

The concept of flood risk is related to the probability that the flood occurs, which results in consequence damages on various aspects, including environmental, economic, and social losses. This study applied the vulnerability understanding of Lewis [16], Gabor and Griffith [17], Balica [18], Belical et al. [19], and Saudi et al. [6] that is the root cause of disasters and certain hazards like climate change, environmental hazards, and flood. Balica et al. [19] and Karmaoui et al. [20] also proposed the process to determine the FRI based on four 
components, which are social, economic, environmental and physical, and their interactions. They are linked with the factors of vulnerability: exposure, susceptibility, and resilience, as the conceptual FRI equations is:

$$
F R I=\frac{E \times S}{R}
$$

where $\mathrm{E}=$ Exposure

$$
\mathrm{S} \quad=\text { Susceptibility }
$$$$
\mathrm{R}=\text { Resilience }
$$

Exposure, susceptibility, and resilience are three important factors that considerably reflect the flood risk of the concerned area. Dao et al. [21] described exposure as the scope that human settlements and people lives while susceptibility is exposed factors in the system, which affects the probabilities of being harmed during floods [22]. Resilience is the adaptation capacity of each community to changes in the hazardous area by modifying itself to achieve an acceptable structural and functional level [23].

However, in this study, since the land-use change is notified as the important factor that induces a different level of flood damage; therefore, the meaning of each factor has been locally modified as described below:-

- Exposure $(\mathbf{E})$ is the variable that represents the damages caused by immediate contact with the flood event. The related parameters are the initial water level, the flood runoff, the rainfall, and distance of that considered city from the river.

- Susceptibility (S) is the fact of being damaged by the flood. The factors that are considered in this variable such as population, size of the city, or even when the agricultural areas close to the city.

- Resilience (R) is the ability to withstand the problem. The factors in this set of variables consist of the receiving area, quality of drainage system, amount of drainage covers the area of the city, flood protection cover area, including the flood warning system.

\subsection{FRI Parameters Sensitivity Study}

FRI is the index which links factors of vulnerability which are exposure, susceptibility, and resilience. Each variable consists of various factors, in which depends on the characteristics of the concerned area.

Consequently, in order to evaluate the effect degree of land-use change on the local flood risk, the flow and flood behaviors, according to the land-use change, each land-use type in the study area was divided into 20 sub-areas with fixed water and wetland areas. Then, the proportion of forest area, agricultural area and urban area were varied. The HEC-GeoHMS and Hec-GeoRas models were

$$
E=\left[\frac{\text { Agi, Rain }, F D}{R D, \text { Pd,Topo }}\right]
$$

subsequently applied to assess the changes in water levels and inundation areas.

The results in Fig. 13 shows an inverse relationship of forest area and water levels downstream, namely the increase of forest areas at the upstream induces the decrease of average water level at three major cities downstream. However, the increase in the agricultural area and urban area cause the increase of water levels downstream under the shorten travel time from the upstream through the outlet.
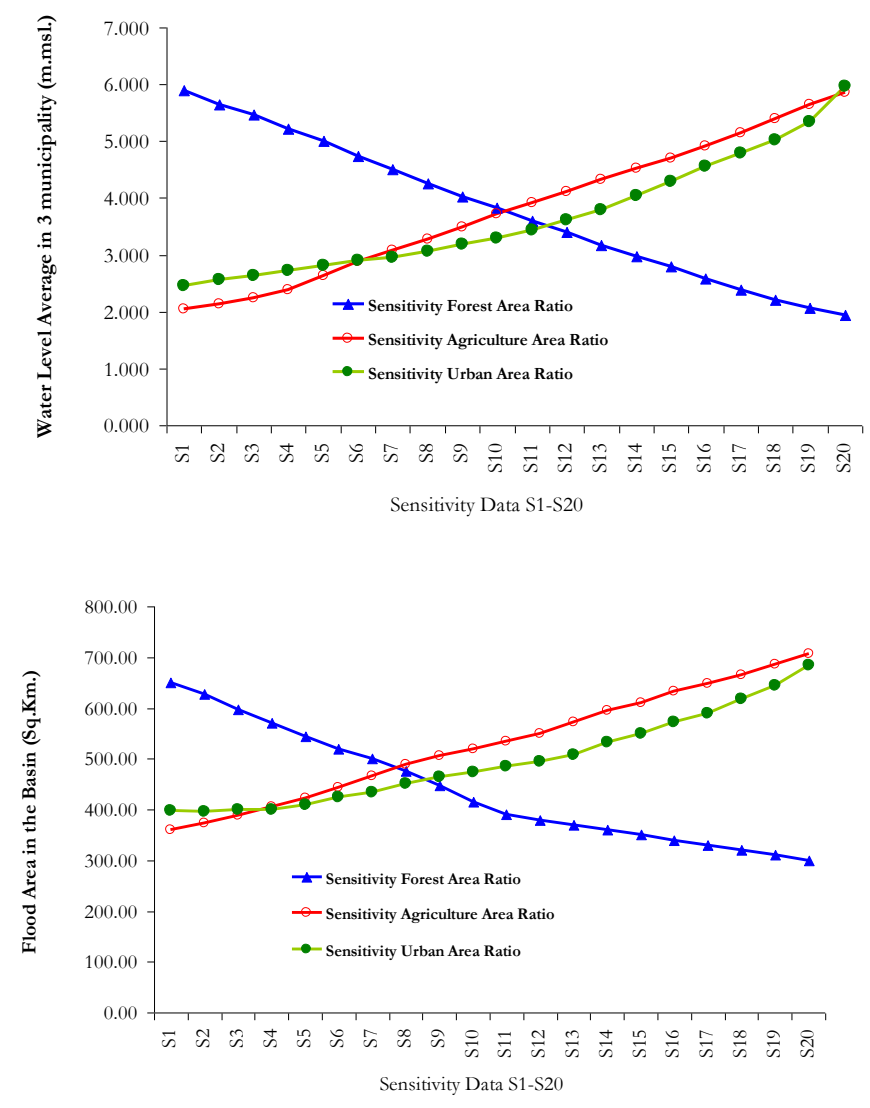

Fig. 13. Result of sensitivity analysis.

Therefore, taking the land-use patterns into primary variables in Eq. (1), the forest, water area, and wetland are defined in the main variable $\mathrm{R}$ (Resilience). The agricultural area is designated as the main variable $\mathrm{E}$ (Exposure) since it has a large area. Thus, it has the potential to increase the risk of flood and affect the cities nearby. In the case of urban areas, that are sensitive and directly affected by flood risk, it is defined as the main variable S (Susceptibility).

Based on the study of Balica et al., 2013, sub-19variable that comprise the main factors were selected. The definition of each variable and variable classification are shown in Table 5.

For the equation in the part of Exposure, according to the factor of $\mathrm{E}$, which has six factors can be formulated as 


$$
\text { Dimension_of_E }=\left[\frac{\left(\mathrm{m}^{2}\right)(\mathrm{m} / \text { year })(\mathrm{hr})}{\left.\left(\mathrm{m}^{3} / \mathrm{s} * 86400 * 365\right)(\text { people })(\%)\right)}\right]
$$

For the equation in the part of Susceptibility, according to the factor of $\mathrm{S}$, which has six factors can be formulated as

$$
S=\left[\frac{U r, U g, Q i}{\operatorname{Ind}, G w l / E v}\right]
$$

Dimension_of_S $=\left[\frac{\left(\mathrm{m}^{2}\right)(\%)(-)}{\left(\mathrm{m}^{2}\right)(\text { m/ year }) /(\text { m } / \text { year })}\right]$

For the equation in the part of Resilience, according to the factor of $\mathrm{R}$, which has seven factors can be formatted as

$$
R=\left[\frac{F r, W e t, F p T, W R s, E s}{S, \text { Drain }}\right]
$$

Dimension_of_R $=\left[\frac{\left(m^{2}+m^{2}\right)(-)(-)(-)}{\left(m^{2}\right)(-)}\right]$

Simplifing the Flood Risk Index, all variables have to be normalized and converted into a common range, assuming values 0 (lowest risk) and 1 (highest risk). Then, the FRI (normalized) equation is shown in Eq. (8)

$$
F R I(\text { normalized })=\frac{(F R I(\text { score }))-K 1)+|K 2-K 1|}{|K 2-K 1|}-1
$$

Where: K1 defined as the best probability score at the specified location

\begin{tabular}{|c|c|c|c|c|c|c|c|}
\hline No & Factor & Abbreviations & $\begin{array}{l}\text { FRI } \\
\text { Factor }\end{array}$ & Unit & $\begin{array}{l}\text { Definition } \\
\text { of indicator }\end{array}$ & $\begin{array}{c}\text { Functional relationship } \\
\text { with Risk }\end{array}$ & Data Source \\
\hline 1 & Agriculture Area & Agri & $E$ & Sq.Km & $\%$ of Agriculture Area in the basin & The higher $\%$, the higher risk & Land use study,DPT, LDD \\
\hline 2 & Population Density & $P d$ & $E$ & people/Sq.Km. & $\begin{array}{l}\text { There is an importante exposure to given } \\
\text { hazard if population is concentrated }\end{array}$ & Higher\# of people, higher risk & Municipalities,DPT \\
\hline 3 & Flood duration & $F D$ & $E$ & day & Time between flood & Higher\#day, the higher risk & Hydological and Flood Study \\
\hline 4 & Rainfall & Rain & $E$ & $\mathrm{~m} /$ Year & The average rainfall/year & Higher rainfall, higher risk & Hydological Study, RID \\
\hline 5 & Topography & Topo & $E$ & - & $\begin{array}{l}\text { Rain }=\left(\mathrm{mm} /\left(1000 *_{\text {year }}\right)\right)=\mathrm{m} / \text { year } \\
\text { average slope of sub-catcment }\end{array}$ & The steeper slope, higher risk & DEM Data,LDD \\
\hline 6 & River Discharge & $R D$ & $E$ & Cu.m./Sec & Maximum river discharge & HigherRD, higher risk & Hydological and Flood Study \\
\hline 7 & Urban area & $U_{r}$ & $s$ & Sq.Km & $\%$ of Uban area in the basin & The higher $\%$, the higher risk & Land use study,DPT, LDD \\
\hline 8 & Industrial area & Ind & $s$ & Sq.Km & $\%$ of Industrial area in the basin & The higher $\%$, the higher risk & Land use study,DPT, LDD \\
\hline 9 & Urban growth & $U g$ & $s$ & $\%$ & $\%$ of increase in urban area & $\begin{array}{l}\text { fast urban growth may result in } \\
\text { poor quality housing and thus } \\
\text { make peple more risk }\end{array}$ & Land use study,DPT, LDD \\
\hline 10 & Quality of Infrasturcture & $Q i$ & $s$ & - & Range between 5-10 & 10 means lower risk & Municipalities \\
\hline 11 & Evaporation rate & $E_{V}$ & $s$ & $\mathrm{~m} /$ Year & yearly evaporation rate & higher Ev, higher risk & Hydological Study \\
\hline 12 & Groundwater Level & Gwl & $s$ & $\mathrm{~m} /$ Year & yearly decrease rate in groundwater Level & Higher Gwl, higher risk & Hydological Study \\
\hline 13 & Forest area & Fr & $\boldsymbol{R}$ & Sq.Km & $\%$ of Forest area in the basin & The higher $\%$, the lower risk & Land use study,DPT, LDD \\
\hline 14 & Water,Wetland Area & Wet & $\boldsymbol{R}$ & Sq.Km & $\%$ of Water,Wetland Area in the basin & The higher $\%$, the lower risk & Land use study,DPT, LDD \\
\hline 15 & Flood Protection & $F p T$ & $\boldsymbol{R}$ & - & Range between 1-10 & 10 means lower risk & Municipalities \\
\hline 16 & Drainage & Drain & $\boldsymbol{R}$ & - & Range between 1-10 & 10 means lower risk & Municipalities \\
\hline 17 & Warning System & WRs & $\boldsymbol{R}$ & - & $\begin{array}{l}\text { if No WRs than the value is } 1 \text {, } \\
\text { if yes WRs than the value is } 10\end{array}$ & Having WRs reduces the risk & RID \\
\hline 18 & Emergency Service & Es & $\boldsymbol{R}$ & - & $\begin{array}{l}\text { number of people working } \\
\text { in this service }\end{array}$ & $\begin{array}{l}\text { bigger\# of people, less risk } \\
\text { they are }\end{array}$ & Municipalities \\
\hline 19 & Shelters & $\mathrm{s}$ & $\boldsymbol{R}$ & -/Sq.Km. & $\begin{array}{l}\text { number of shelters/Sq.Km., } \\
\text { including hospitals }\end{array}$ & bigger\# of $\mathrm{S}$, lower risk & Municipalities \\
\hline
\end{tabular}

K2 defined as the worst possible score at the specified location.

Table 5. Selected sub-19-variable that comprised of variables E, S, and R.

Remarks: (-) is a Score 0-10. 
Table 6. Results of the best cases and the worst cases for K1 and K2.

\begin{tabular}{|c|c|c|c|c|c|c|c|c|c|c|c|}
\hline \multirow[b]{2}{*}{ No } & \multirow[b]{2}{*}{ Factor } & \multirow[b]{2}{*}{ Abbreviations } & \multirow{2}{*}{$\begin{array}{c}\text { FRI } \\
\text { Factor }\end{array}$} & \multirow[b]{2}{*}{ Unit } & \multicolumn{2}{|c|}{ FRI Palpanang } & \multicolumn{2}{|c|}{ FRI ChianYai } & \multicolumn{2}{|c|}{ FRI Hua-sai } & \multirow[b]{2}{*}{ Remark } \\
\hline & & & & & For best Case & For Worst Case & For best Case & For Worst Case & For best Case & For Worst Case & \\
\hline 1 & Agriculture Area & Agri & & $s_{q} . \mathrm{Km}$ & $2,405.85$ & $2,690.75$ & $2,405.25$ & $2,650.75$ & $2,46.85$ & $2,690.75$ & For $A$ Al in the basin \\
\hline 2 & Population Density & $P d$ & $E$ & people $/ \mathrm{sq} . \mathrm{Km}$. & 30.00 & 500.00 & 5000 & 500.00 & 30.00 & $300 . \infty$ & Exch Arumiejplity \\
\hline 3 & Fbod duration & $F D$ & $E$ & hr & 1.00 & 7200 & 100 & 72.00 & 1.00 & 7200 & Eech alrumiepulty \\
\hline 4 & Rainfall & Rain & $E$ & $\mathrm{~m} /$ Yex & 1.20 & 250 & 1.20 & 250 & 1.20 & 230 & For $A$ All in the basin \\
\hline 5 & Topography & $T_{\text {Topo }}$ & E & - & 0.01 & 0.01 & 0.01 & 0.01 & 0.01 & 0.01 & Eech alrumeipultr \\
\hline 6 & River Discharge & $R D$ & $E$ & $\mathrm{Cum} / \mathrm{sec}$ & 100.00 & $1,250.00$ & $85 \infty$ & 450.00 & 50.00 & 450.00 & Exch afrumipaptrty \\
\hline \multicolumn{5}{|c|}{ Talec in $E_{Q} \cdot E$} & $13,557.70$ & $37,196.93$ & 16,30317 & $103,32+.60$ & $17,322.12$ & $109,32+.80$ & \\
\hline 7 & Urban area & $U_{r}$ & $s$ & $\mathrm{~s}_{\mathrm{q} \cdot \mathrm{Km}}$ & $102+40$ & 235.50 & 10240 & 235.50 & $100+40$ & 235.50 & For $A l l$ in the brain \\
\hline 8 & Ind lutrial mea & Ind & $s$ & $\mathrm{~s}_{\mathrm{q}} \mathrm{Km} \mathrm{Km}$ & 16.87 & 4.07 & 16.57 & 4.07 & 10.87 & 4.07 & For $A$ Alfin the basin \\
\hline 9 & Urban growth & $v_{g}$ & $s$ & $\%$ & 0.05 & 0.60 & 0.05 & 0.60 & 0.05 & 0.00 & 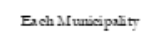 \\
\hline 10 & Quality of Infrast turcture & $Q^{i}$ & $s$ & - & 10.00 & 5.00 & 1000 & 5.00 & 10.00 & 5.00 & 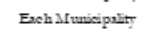 \\
\hline 11 & Eraporation rate & $E_{V}$ & $s$ & $\mathrm{~m} /$ Yex & 1.50 & 250 & 1.30 & 250 & 1.50 & 250 & For $A l l$ in the basin \\
\hline 12 & Groundwater Level & $G \pi I$ & $s$ & $\mathrm{~m} /$ Yex & 1.00 & 200 & 100 & 200 & 1.00 & 200 & For Allin the basin \\
\hline \multicolumn{5}{|c|}{ Tale in Eq.. $\mathrm{S}$} & 4.55 & 217.09 & 4.55 & 217.09 & 4.55 & $217 . \infty$ & \\
\hline 13 & Forest area & $F r$ & $\boldsymbol{R}$ & $\mathrm{sq}_{9} \cdot \mathrm{km}$ & 451.40 & 256.50 & 461.40 & 258.50 & 461.40 & 258.50 & For $A$ Al in the bxin \\
\hline 14 & Water, Wetland Area & Wet & ${ }_{R}$ & $\mathrm{sq}_{\mathrm{q}}^{\mathrm{Km}}$ & 239.70 & 57.40 & 239.70 & 37,40 & 239.70 & 37.40 & For $A$ Al in the basin \\
\hline 15 & Fbood Protection & $F_{p} T$ & ${ }_{R}$ & - & 10.00 & 1.00 & 1000 & 1.00 & 10.00 & 1.00 & 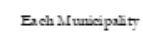 \\
\hline 16 & Drainage & Drain & $\boldsymbol{R}$ & - & 10.00 & 1.00 & 1000 & 1.00 & 10.00 & 1.00 & 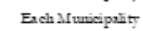 \\
\hline 17 & Warring System & WRS & ${ }_{R}$ & - & 10.00 & 1.00 & 1000 & 1.00 & 10.00 & 1.00 & For $A$ Al in the brain \\
\hline 18 & Emergency Service & Es & ${ }_{R}$ & - & 500.00 & 10.00 & 50000 & 10.00 & 500.00 & 10.00 & 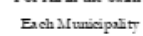 \\
\hline 19 & Shertes & $\mathrm{s}$ & ${ }_{R}$ & $-/ \mathrm{sq}_{\mathrm{q}} \mathrm{Km}$ & 10.00 & 1.00 & 1000 & 1.00 & 10.00 & 1.00 & 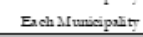 \\
\hline \multicolumn{5}{|c|}{$T$ ale in $E_{9} . R$} & $350,550.00$ & $2,958,00$ & $350,550, \infty$ & 295900 & $350,550.00$ & $2,959.00$ & \\
\hline \multicolumn{5}{|c|}{$\mathrm{FRI}=\left(\mathrm{E}^{*} \mathrm{~S}\right) / \mathrm{R}$} & $\begin{array}{|ll|}\mathbf{K} 1 & \\
\end{array}$ & $\mathbf{K} 2$ & $\begin{array}{ll}\mathbf{K} 1 & \\
0.21 & \\
\end{array}$ & $\mathrm{~K}_{7,580.55}$ & $\mathbf{x} 1$ & \begin{tabular}{|l|}
$\mathbf{K} 2 \mathbf{2}$ \\
$7,550.55$ \\
\end{tabular} & \\
\hline \multicolumn{5}{|c|}{ Normalized PRI Value $0-1$} & 0 & 1 & 0 & 1 & 0 & 1 & \\
\hline
\end{tabular}

Table 7. Results of FRIs determination, under actual land-use of 2012 and 2014.

\begin{tabular}{|c|c|c|c|c|c|c|c|c|c|c|c|}
\hline \multirow[b]{2}{*}{ No } & \multirow[b]{2}{*}{ Factor } & \multirow[b]{2}{*}{ Abbreviations } & \multirow{2}{*}{$\begin{array}{c}\text { FRI } \\
\text { Factor }\end{array}$} & \multirow[b]{2}{*}{ Unit } & \multicolumn{2}{|c|}{ FRI Pakpanang } & \multicolumn{2}{|c|}{ FRI ChianYai } & \multicolumn{2}{|c|}{ FRI Hua-Sai } & \multirow[b]{2}{*}{ Remark } \\
\hline & & & & & 2012 & 2014 & 2012 & 2014 & 2012 & 2014 & \\
\hline 1 & \begin{tabular}{|l|} 
Agriculture Area \\
\end{tabular} & Agri & $E$ & Sq.Km & $2,534.71$ & $2,543.89$ & $2,534.71$ & $2,543.89$ & $2,534.71$ & $2,543.89$ & For All in the basin \\
\hline 2 & Population Density & $P d$ & E & people/Sq.Km. & 40.00 & 150.00 & 60.00 & 150.00 & 50.00 & 150.00 & Each Municipality \\
\hline 3 & Flood duration & $F D$ & E & hr & 60.00 & 65.00 & 45.00 & 80.00 & 45.00 & 55.00 & Each Municipality \\
\hline 4 & Rainfall & Rain & E & $\mathrm{m} /$ Year & 1.20 & 1.20 & 1.20 & 1.20 & 1.20 & 1.20 & For All in the basin \\
\hline 5 & Topography & Topo & E & - & 0.01 & 0.01 & 0.01 & 0.01 & 0.01 & 0.01 & Each Municipality \\
\hline 6 & River Discharge & $R D$ & $E$ & Cu.m./Sec & 967.00 & 610.00 & 124.60 & 130.00 & 160.00 & 120.00 & Each Municipality \\
\hline \multicolumn{5}{|c|}{ Take in Eq. E } & $113,236.27$ & $52,045.49$ & $439,403.98$ & $300,570.39$ & $410,623.02$ & $223,862.32$ & \\
\hline 7 & Urban area & Ur & $s$ & Sq.Km & 218.63 & 220.99 & 218.63 & 220.99 & 218.63 & 220.99 & For All in the basin \\
\hline 9 & Urban growth & $U g$ & $s$ & $\%$ & 0.05 & 0.10 & 0.10 & 0.10 & 0.10 & 0.10 & Each Municipality \\
\hline 10 & Quality of Infrasturcture & $Q i$ & $s$ & - & 5.00 & 5.00 & 4.00 & 4.00 & 5.00 & 5.00 & Each Municipality \\
\hline 11 & Evaporation rate & $E_{V}$ & $s$ & $\mathrm{~m} /$ Year & 1.50 & 1.50 & 1.50 & 1.50 & 1.50 & 1.50 & For All in the basin \\
\hline 12 & Groundwater Level & $G w I$ & $s$ & $\mathrm{~m} /$ Year & 1.50 & 1.50 & 1.50 & 1.50 & 1.50 & 1.50 & For All in the basin \\
\hline \multicolumn{5}{|c|}{ Take in Eq. $\mathrm{S}$} & 3.58 & 7.24 & 5.73 & 5.79 & 7.16 & 7.24 & \\
\hline 13 & Forest area & Fr & $R$ & Sq.Km & 324.80 & 337.77 & 324.80 & 337.77 & 324.80 & 337.77 & For All in the basin \\
\hline 14 & Water,Wetland Area & Wet & $R$ & Sq.Km & 132.82 & 108.31 & 132.82 & 108.31 & 132.82 & 108.31 & For All in the basin \\
\hline 15 & Flood Protection & $F p T$ & $R$ & - & 5.00 & 5.00 & 5.00 & 5.00 & 5.00 & 5.00 & Each Municipality \\
\hline 16 & Drainage & Drain & $R$ & - & 5.00 & 5.00 & 5.00 & 5.00 & 5.00 & 5.00 & Each Municipality \\
\hline 17 & Warning System & WRs & $R$ & - & 2.00 & 2.00 & 2.00 & 2.00 & 2.00 & 2.00 & For All in the basin \\
\hline 19 & Shelters & $\mathrm{s}$ & $R$ & $-/$ Sq.Km. & 1.00 & 2.00 & 1.00 & 2.00 & 1.00 & 2.00 & Each Municipality \\
\hline \multicolumn{5}{|c|}{ Take in Eq. $\mathbf{R}$} & $91,524.00$ & $44,608.00$ & $91,524,00$ & $44,608.00$ & $91,524,00$ & $44,608.00$ & \\
\hline \multicolumn{5}{|c|}{$\mathrm{FRI}=(\mathrm{E} * \mathrm{~S}) / \mathrm{R}$} & 4.43 & 8.45 & 27.51 & 39.03 & 32.14 & 36.34 & \\
\hline \multicolumn{5}{|c|}{ Normalized FRI Value Score Theshold 0-1 } & 0.16 & 0.30 & 0.36 & 0.51 & 0.42 & 0.48 & \\
\hline
\end{tabular}

\subsection{Spatial FRI Score}

In order to obtain the FRI scores, $\mathrm{K} 1$ and $\mathrm{K} 2$ values of three municipalities, Pakpanang, Chianyai, and Hua-sai were estimated firstly. The hydrological model and hydraulic model were applied to several flood scenarios. The results of the best case and the worst case, as shown in Table 6, were taken to define the upper and lower boundaries of $\mathrm{K} 1$ and $\mathrm{K} 2$ of each city. follows:

The values of $\mathrm{K} 1, \mathrm{~K} 2$ of each municipality are as

$$
\begin{array}{ll}
\text { K1, K2 Pakpanang } & =0.18,2729.00 \\
\text { K1,K2 Chianyai } & =0.21,7580.55 \\
\text { K1,K2 Hua-Sai } & =0.22,7580.55
\end{array}
$$

Substitute $\mathrm{K} 1$ and $\mathrm{K} 2$, with the related variables, as shown in Table 7, to Eq. (2), (3), (4), and (8) by applying the rainfall data of flood on the actual land-use in 2012, and 2014, the cruelty of flood was studied. It was found that both spatial and temporal degrees of severity of flood varied to the land-use change, as shown in Fig. 14. The ratio of Urban: Agricultural Area: Forest: Wetland are 218.63, 2534. 71, 324.80, 132.82 and 220.99, 2543.89, $337.77,108.31$ in the year 2012, and 2014, respectively.

The FRIs of Pakpanang, Chianyai, and Hua-sai are $0.16,0.36$, and 0.42 , in 2012, whereas the FRIs of these three municipal are $0.30,0.51$, and 0.48 , in 2014. It indicates that the actual change of land-use in which the water/wetland was significantly replaced by the urban and agricultural area, induces the higher flood risk in all three municipalities. 


\subsection{FRI in the Future}

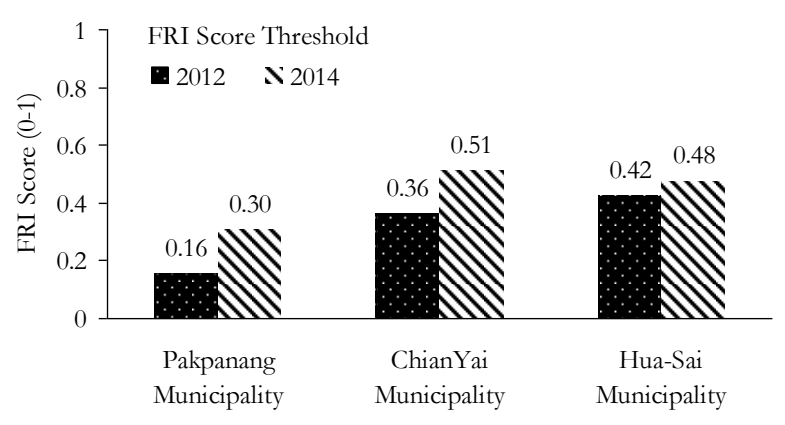

Fig. 14. Spatial and Temporal comparisons of FRI in three municipalities in 2012 and 2014 (Actual land-use conditions).

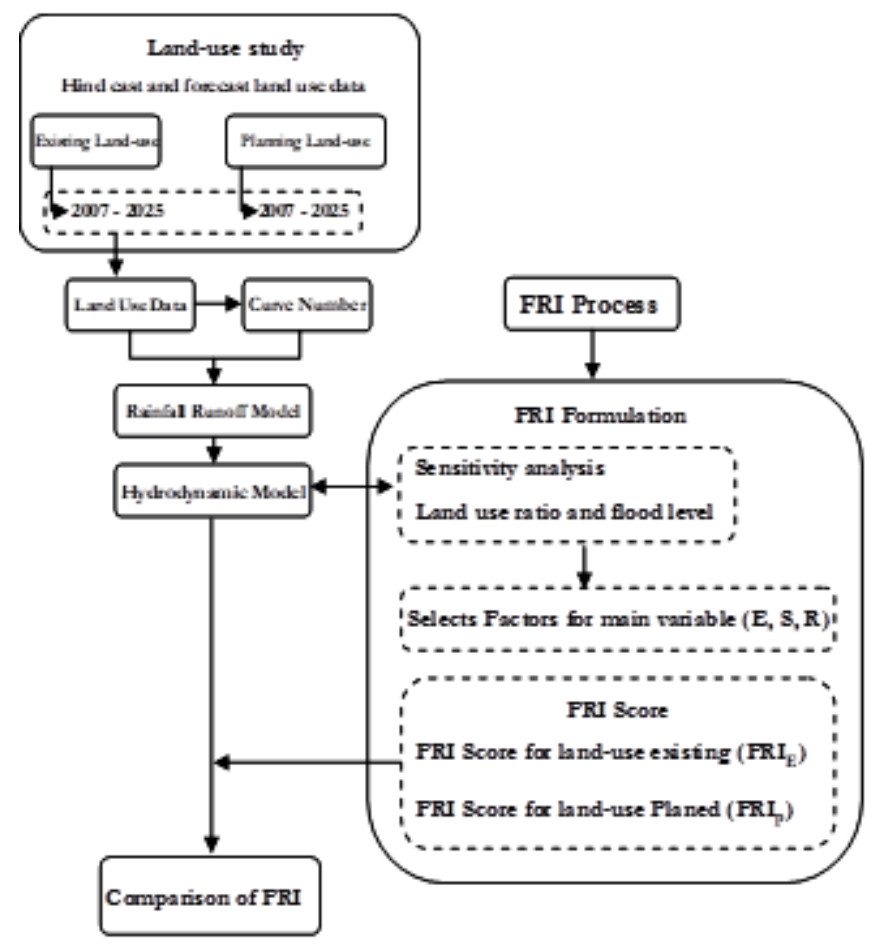

Fig. 15. Comparison process of FRIs, between $\mathrm{FRI}_{\mathrm{E}}$ under actual land-use and $\mathrm{FRI}_{\mathrm{p}}$ under planned land-use.

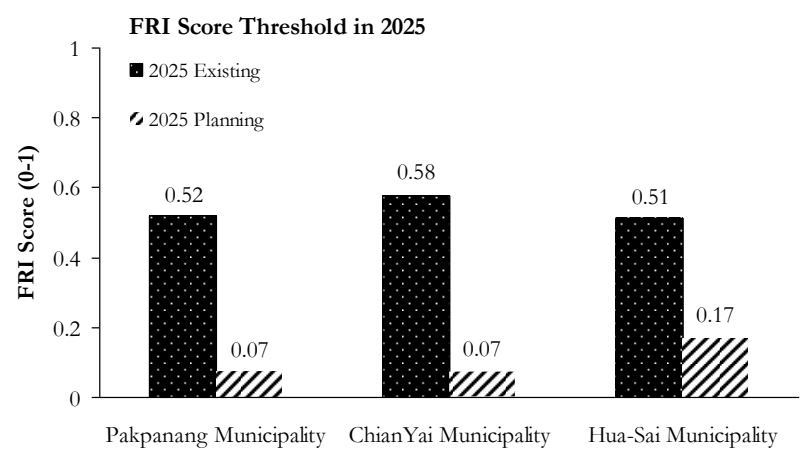

Fig. 16. Comparisons of FRIs of three municipalities in 2025, under conditions of the actual land-use and the planned land-use.
Applying CA Markov model, the 2025 land-use patterns of the study area, based on the actual land-use and based on the DPT planned land-use, were projected. The FRIs of three municipalities under two conditions of landuse changes were evaluated, as the process shown in Fig. 15.

The results, as shown in Table 8 and Fig. 16, clearly indicate that without land-use planning, in 2025, the changes of Pakpanang, Chianyai, and Hua-Sai cause higher flood risk compared with the cities under land-use planned. The FRIs of all municipalities under the actual land-use changes are significantly high, especially in HuaSai that is the most downstream city. It reveals that the implementation of land-use planning, by DPT, is important and necessary, according to the local flood risk in the future.

\section{Conclusions}

Pakpanang River Basin, which is located on the Southern peninsular of Thailand, has been affected by the seasonal flood from August to January. Based on the reports from LDD, the coverage inundation area has been expanded over the last ten years, as a result of both natural and anthropogenic influences. The land-use changes in 2002, 2007, 2012, and 2014, in three municipalities; Pakpanang, Chianyai, and Hua-sai, show 12\% yearly increase in agricultural area, with $15 \%, 18 \%$ and $10 \%$ of yearly decrease of urban, forest, and wetland, respectively. However, due to the scarcity of land-use data, the hind cast land-use of the missing years and forecast land-use of the future, were analyzed by using CA Markov model. The result of LULC spatial-temporal changes was then applied to HEC-HMS, with Arc GIS extension of HECGeoHMS software, in order to evaluate the flood hydrographs corresponding to 100 -year return period rainfall. The result showed that the planned land-use pattern provides less peak flow and shorter drainage time, compare with the events in existing conditions. It indicated that the actual situation

of land-use might induce a higher tendency of flood severity, compare with the planned land-use.

Further, Flood Risk Index (FRI), which links factors of vulnerability; exposure (E), susceptibility (S), and resilience $(\mathrm{R})$, of three municipalities were quantified. It was found that sensitivity analysis in the area of forest on flood depth and inundation areas is incoherent. Taking the land-use patterns into primary variables; the forests, water areas, and wetland were defined in the main variable $\mathrm{R}$, the agricultural area was designated as the main variable $E$, and the urban area that is sensitive and directly affected by flood risk, was defined as the main variable $\mathrm{S}$. The FRI under the existing land-use(FRI $\left.\mathrm{F}_{\mathrm{E}}\right)$ and the planned landuse $\left(\mathrm{FRI}_{\mathrm{P}}\right)$ of the year 2025 are as follows:- 

$\begin{array}{ll}\text { - Pakpanang: } & \mathrm{FRI}_{\mathrm{E}}=0.52, \mathrm{FRI}_{\mathrm{P}}=0.07, \\ & \mathrm{FRI}_{\mathrm{P}} / \mathrm{FRI}_{\mathrm{E}}=86.17 \%\end{array}$

- Chianyai:

$\mathrm{FRI}_{\mathrm{E}}=0.58, \mathrm{FRI}_{\mathrm{P}}=0.07$, $\mathrm{FRI}_{\mathrm{P}} / \mathrm{FRI}_{\mathrm{E}}=87.46 \%$

- Hua-sai, :

$\mathrm{FRI}_{\mathrm{E}}=0.51, \mathrm{FRI}_{\mathrm{P}}=0.17$, $\mathrm{FRI}_{\mathrm{P}} / \mathrm{FRI}_{\mathrm{E}}=67.06 \%$
$\mathrm{FRI}_{\mathrm{E}}$ of all considered cities is higher than FRIp. It implies that without land-use planning, the changes in LULC changes cause higher flood risk, in which the riskiest city is Chianyai. The FRI $\mathrm{E}_{\mathrm{E}}$ and FRI proportion, additionally, indicate the FRI deviation due to LULC Changes that is not according to plan. Therefore, to reduce the flood risk, all cities need to be LULC changed back to be in line with the plan. Hence, Chainyai would need the most resources and highest effort in comparison to Chianyai and Hua-sai.

Table 8. Comparisons of FRI in 2025 under condition of actual land-use and planned land-use.

\begin{tabular}{|c|c|c|c|c|c|c|c|c|c|c|c|}
\hline \multirow[b]{2}{*}{ No } & \multirow[b]{2}{*}{ Factor } & \multirow[b]{2}{*}{ Abbreviations } & \multirow{2}{*}{$\begin{array}{c}\text { FRI } \\
\text { Factor }\end{array}$} & \multirow[b]{2}{*}{ Unit } & \multicolumn{2}{|c|}{ FRI Pakpanang } & \multicolumn{2}{|c|}{ FRI CheinYai } & \multicolumn{2}{|c|}{ FRI Hua-Sai } & \multirow[b]{2}{*}{ Remark } \\
\hline & & & & & Existing(FRI $\left.{ }_{\mathrm{E}}\right)$ & Planning(FRI $\left.\mathrm{F}_{\mathrm{P}}\right)$ & Existing(FRI $\left.{ }_{E}\right)$ & Planning(FRI Fr $_{\mathrm{P}}$ & Existing(FRI $\left.{ }_{\mathrm{E}}\right)$ & Planning(FRI ${ }_{\mathrm{P}}$ ) & \\
\hline 1 & Agriculture Area & Agri & $E$ & Sq.Km & $2,527.71$ & $2,658.99$ & $2,527.71$ & 2,658.99 & $2,527.71$ & 2,658.99 & For All in the basin \\
\hline 2 & Population Density & $P d$ & $E$ & people/Sq.Km. & 30.00 & 150.00 & 60.00 & 150.00 & 50.00 & 150.00 & Each Municipality \\
\hline 3 & Flood duration & $F D$ & $E$ & hr. & 20.00 & 15.00 & 18.00 & 22.00 & 22.00 & 22.00 & Each Municipality \\
\hline 4 & Rainfall & Rain & $E$ & $\mathrm{~m} /$ Year & 1.20 & 1.20 & 1.20 & 1.20 & 1.20 & 1.20 & For All in the basin \\
\hline 5 & Topography & Topo & E & - & 0.01 & 0.01 & 0.01 & 0.01 & 0.01 & 0.01 & Each Municipality \\
\hline 6 & River Discharge & $R D$ & $E$ & Cu.m./Sec & 960.00 & 850.00 & 282.00 & 234.00 & 129.50 & 102.60 & Each Municipality \\
\hline \multicolumn{5}{|c|}{ Take in Eq. E } & $50,554.20$ & $9,009.28$ & $77,444.73$ & $47,998.18$ & $247,344.72$ & $109,469.53$ & \\
\hline 7 & Urban area & $U_{r}$ & $s$ & Sq.Km & 235.53 & 102.40 & 235.53 & 102.40 & 235.53 & 102.40 & For All in the basin \\
\hline 8 & Industrial area & Ind & $s$ & Sq.Km & 13.86 & 37.88 & 13.86 & 37.88 & 13.86 & 37.88 & For All in the basin \\
\hline 9 & Urban growth & $U g$ & $s$ & $\%$ & 0.30 & 0.50 & 0.30 & 0.50 & 0.30 & 0.50 & Each Municipality \\
\hline 10 & Quality of Infrasturcture & $Q i$ & $s$ & - & 5.00 & 5.00 & 4.00 & 4.00 & 5.00 & 5.00 & Each Municipality \\
\hline 11 & Evaporation rate & $E_{V}$ & $s$ & $\mathrm{~m} /$ Year & 1.50 & 1.50 & 1.50 & 1.50 & 1.50 & 1.50 & For All in the basin \\
\hline 12 & Groundwater Level & $G w l$ & $s$ & $\mathrm{~m} /$ Year & 1.50 & 1.50 & 1.50 & 1.50 & 1.50 & 1.50 & For All in the basin \\
\hline \multicolumn{5}{|c|}{ Take in Eq. $S$} & 25.49 & 6.76 & 20.39 & 5.41 & 25.49 & 6.76 & \\
\hline 13 & Forest area & Fr & $R$ & Sq.Km & 389.46 & 389.07 & 389.46 & 389.07 & 389.46 & 389.07 & For All in the basin \\
\hline 14 & Water,Wetland Area & Wet & $R$ & $\mathrm{Sq} \cdot \mathrm{Km}$ & 59.66 & 37.88 & 59.66 & 37.88 & 59.66 & 37.88 & For All in the basin \\
\hline 15 & Flood Protection & $F_{p} T$ & $R$ & - & 5.00 & 10.00 & 5.00 & 10.00 & 5.00 & 10.00 & Each Municipality \\
\hline 16 & Drainage & Drain & $R$ & - & 5.00 & 5.00 & 5.00 & 5.00 & 5.00 & 5.00 & Each Municipality \\
\hline 17 & Warning System & WRs & $R$ & - & 2.00 & 2.00 & 2.00 & 2.00 & 2.00 & 2.00 & For All in the basin \\
\hline 18 & Emergency Service & Es & $R$ & - & 100.00 & 50.00 & 40.00 & 80.00 & 180.00 & 100.00 & Each Municipality \\
\hline 19 & Shelters & $\mathrm{s}$ & $R$ & $-/ \mathrm{Sq} \cdot \mathrm{Km}$. & 1.00 & 3.00 & 1.00 & 3.00 & 1.00 & 3.00 & Each Municipality \\
\hline \multicolumn{5}{|c|}{ Take in Eq. $\mathbf{R}$} & $89,824.00$ & $28,463.33$ & $35,929.60$ & $45,541.33$ & $161,683.20$ & $56,926.67$ & \\
\hline \multicolumn{5}{|c|}{$F R I=(E * S) / R$} & 14.35 & 2.14 & 43.95 & 5.70 & 39.00 & 13.00 & \\
\hline \multicolumn{5}{|c|}{ Normalized FRI Value Score Theshold 0-1 } & 0.52 & 0.07 & 0.58 & 0.07 & 0.51 & 0.17 & \\
\hline
\end{tabular}

\section{References}

[1] United Nations, Proceedings of the Seminars on Flood $V$ ulnerability Analysis and on the Principles of Floodplain Management for Flood Loss Prevention / Economic and Social Commission for Asia and the Pacific-Seminar on Flood Vulnerability Analysis. New York: United Nations, 1982, pp. 67-70.

[2] A. Sadeghi-Pouya, J. Nouri, N. Mansouri, and A. Kia-Lashaki, "Developing an index model for flood risk assessment in the western coastal region of Mazandaran, Iran," J. Hydrol. Hydromech., vol. 65, pp. 134-145, 2017.

[3] A. Goncalo, B. Bouchard, M. Susienka, and K. Wilson, "Improving flood risk management in informal settlements of Cape Town," An Interactive Qualifying Project submitted to the Faculty of Worcester Polytechnic Institute in partial fulfilment of the requirements for the Degree of Bachelor of Science, Roads \& Stormwater Department, City of Cape Town, 2007.

[4] V. Cançado, L. Brasil, N. Nascimento, and A. Guerra, "Flood risk assessment in an urban area: Measuring hazard and vulnerability," in 11th International
Conference on Urban Drainage, Edinburgh, Scotland, UK, 2008, pp. 1-10.

[5] Y. Okazawa, P. J.-F. Yeh, S. Kanae, and T. Oki, "Development of a global flood risk index based on natural and socio-economic factors," Hydrological Sciences Journal - Journal des Sciences Hydrologiques, vol. 56, no. 5, pp. 789-804, 2011.

[6] A. S. M. Saudi, M. K. A. Kamarudin, I. S. D. Ridzuan, R. Ishak, A. Azid, and Z. I. Rizman, "Flood risk index pattern assessment: Case study in Langat river basin," Journal of Fundamental and Applied Sciences, vol. 9, no. 2S, pp. 12-27, 2017.

[7] A. Karmaoui, Decision Support Methods for Assessing Flood Risk and Vulnerability (Advances in Environmental Engineering and Green Techonlogies (AEEGT)). IGI Global, 2020.

[8] N. Q. Omar, S. A. M. Sanusi, W. M. W. Hussin, N. Samat, K. S. Mohammed, "Markov-CA model using analytical hierarchy process and multiregression Technique," in 7th IGRSM International Remote Sensing \& GIS Conference and Exbibition, IOP Conf. Series: Earth and Environmental Science 20, 2014, pp. 1-17.

[9] M. S. Mondal, N. Sharma, P. K. Garg, and M. Kappas, "Statistical independence test and validation of CA Markov land use land cover (LULC) 
prediction results," The Egyptian Journal of Remote Sensing and Space Science, vol. 19, no. 2, pp. 259-272, 2016.

[10] R. G. Pontius Jr. and J. Malanson, "Comparison of the structureand accuracy of two land change models," Int. J. Geogr. Inf. Sci., vol. 19, no. 2, pp. 243 265, 2005.

[11] J. Nouri, A. Gharagozlou, R. Arjmandi, S. Faryadi, M. Adl, "Predicting urban land use changes using a CA-Markov model," Arab J Sci Eng vol. 39, pp. 5565-5573, 2014.

[12] A. K. Hua, "Application of CA-Markov model and land use/land cover changes in Malacca river watershed, Malaysia," Applied Ecology and Environmental Research, vol. 15, no. 4, pp. 605-622, 2017.

[13] I. K. Jung, J. Y. Park, G. A. Park, M. S. Lee, and S. J. Kim, "A grid-based rainfall-runoff model for flood simulation including paddy fields," Paddy and Water Environment, vol. 9, no. 3, pp. 275-290, 2011.

[14] M. Ali, S. J. Khan, I. Aslam, and Z. Khan, "Simulation of the impacts of land-use change on surface runoff of Lai Nullah Basin in Islamabad, Pakistan," Landscape and Urban Planning, vol. 102, no. 4, pp. 271-279, 2011.

[15] P. E. Zope, T. I. Eldho, and V. Jothiprakash, "Impacts of land use-land cover change and urbanization on flooding: A case study of Oshiwara River Basin in Mumbai, India," Catena, vol. 145, pp. 142-154, 2016.

[16] J. Lewis, Development in Disaster-Prone Places. London: Intermediate Technology Publications, 1999.
[17] T. Gabor and T. K. Griffith, "The assessment of community vulnerability to acute hazardous materials incidents," Journal of Hazardous Materials, vol. 8, pp. 323-22, 1980.

[18] S. F. Balica, "Applying the flood vulnerability index as a knowledge base for flood risk assessment," doctoral dissertation, Delft University of Technology and UNESCO-IHE Institute for Water Education, the Netherlands, 2012.

[19] S. F. Balica, I. Popescu, L. Beevers, and N. G. Wright, "Parametric and physically based modelling techniques for flood risk and vulnerability assessment: A comparison," Environ. Model. Software, vol. 41, pp. 84-92, 2013.

[20] A. Karmaoui, S. F. Balica, and M. Messouli, "Analysis of applicability of flood vulnerability index in Pre-Saharan region, a pilot study to assess flood in Southern Morocco," Journal Nat. Hazards Earth Syst. Sci., pp. 1-24, 2016.

[21] Q. H. Dao and P. Peduzzi, "Global evaluation of human risk and vulnerability to natural hazards," in Enviroinfo 2004, Sh@ring, Editions du Tricorne, Genève. Genève, 2004, vol. I, pp. 435-446.

[22] UNDP/BCPR, Reducing Disaster Risk. A Challenge for Development. New York: UNDP/Bureau for Crisis Prevention and Recovery, 2004. Available: http://www.undp.org/ bcpr/disred/rdr.htm

[23] A. Galderisi, "Enhancing urban resilience in face of climate change: A methodological approach," TeMA - Journal of Land Use, Mobility and Environment, pp. 69$87,2012$. 


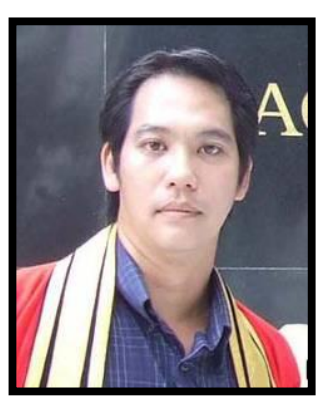
First . Author : Mr. Chonlatid Kittikhun
Date of birth : $\quad 21$ July 1976
Place of birth : $\quad$ Bangkok
Nationlity : Thai
Education :

B.Ind.(Civil engineering), South-East Asia University, Bangkok, Thailand, 2003

- M.Eng.(Water Resources engineering), King Mongkut's University of Technology Thonburi, Bangkok, Thailand

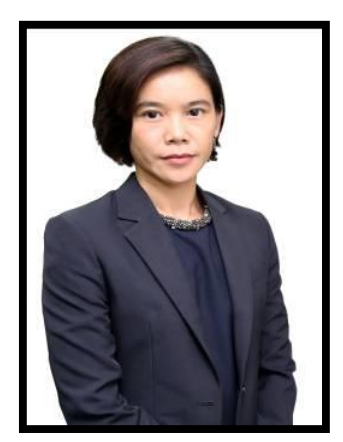

Second Author : $\quad$ Assistant Professor Sitang Pilailar

Date of birth : -

Place of birth : $\quad$ Bangkok

Nationlity : Thai

Education :

B.Eng.(Environmental engineering), Chiang-Mai University, Chiang-Mai, Thailand, 1997

M.Eng.(Water Supply,Drainage\&Sewerage engineering), Asian Institute of Technology, Bangkok, Thailand, 2001

Ph.D.(Water Resources engineering), Tohoku Unoversity, Japan, 2004

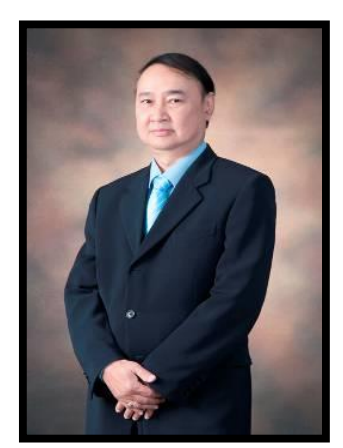

$\begin{array}{lll}\text { Third Author } & : & \text { Professor Suwatana Chittaladakorn } \\ \text { Date of birth } & : & - \\ \text { Place of birth } & : & \text { Bangkok } \\ \text { Nationlity } & : & \text { Thai }\end{array}$

Education :

B.Eng.(Irrigation engineering), Kasetsart University, Bangkok, Thailand

- M.Eng.( Irrigation engineering), Kasetsart University, Bangkok,Thailand

- Ph.D.( Irrigation engineering), Utah State University, USA

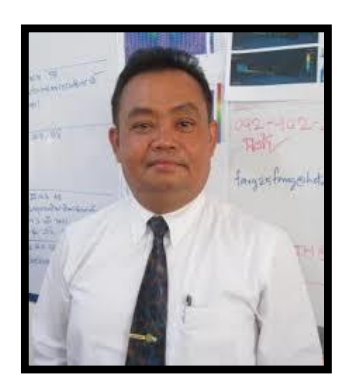

Fourth Author :

Date of birth :

Dr. Eakawat Jhonpadit

Place of birth :

Bangkok

Nationlity : Thai

Education :

B.Eng.(Irrigation engineering), Kasetsart University, Bangkok, Thailand

M.Eng.( Irrigation engineering), Kasetsart University, Bangkok, Thailand

Ph.D.( Water Resources engineering), Kasetsart University, Bangkok, Thailand 